\title{
Beroepenmodel voor het onderwijs en de zorg: werkgelegenheid en prognoses
}

Citation for published version (APA):

Cörvers, F., \& Dupuy, A. (2007). Beroepenmodel voor het onderwijs en de zorg: werkgelegenheid en prognoses. Researchcentrum voor Onderwijs en Arbeidsmarkt, Faculteit der Economische

Wetenschappen. ROA Working Papers No. 3 https://doi.org/10.26481/umarow.2007003

Document status and date:

Published: 01/01/2007

DOI:

10.26481/umarow.2007003

Document Version:

Publisher's PDF, also known as Version of record

\section{Please check the document version of this publication:}

- A submitted manuscript is the version of the article upon submission and before peer-review. There can be important differences between the submitted version and the official published version of record.

People interested in the research are advised to contact the author for the final version of the publication, or visit the DOI to the publisher's website.

- The final author version and the galley proof are versions of the publication after peer review.

- The final published version features the final layout of the paper including the volume, issue and page numbers.

Link to publication

\footnotetext{
General rights rights.

- You may freely distribute the URL identifying the publication in the public portal. please follow below link for the End User Agreement:

www.umlib.nl/taverne-license

Take down policy

If you believe that this document breaches copyright please contact us at:

repository@maastrichtuniversity.nl

providing details and we will investigate your claim.
}

Copyright and moral rights for the publications made accessible in the public portal are retained by the authors and/or other copyright owners and it is a condition of accessing publications that users recognise and abide by the legal requirements associated with these

- Users may download and print one copy of any publication from the public portal for the purpose of private study or research.

- You may not further distribute the material or use it for any profit-making activity or commercial gain

If the publication is distributed under the terms of Article $25 \mathrm{fa}$ of the Dutch Copyright Act, indicated by the "Taverne" license above, 


\title{
Beroepenmodel voor het onderwijs en de zorg: werkgelegenheid en prognoses
}

\author{
Frank Cörvers \\ Arnaud Dupuy \\ ROA-W-2007/3 \\ Juni 07
}

Researchcentrum voor

Onderwijs en Arbeidsmarkt

Postbus 616

6200 MD Maastricht

E-mail: secretary@,roa.unimaas.nl

Internet:www.roa.unimaas.nl

Universiteit Maastricht

Faculteit der Economische Wetenschappen \& Bedrijfskunde 
ISBN: 978-90-5321-457-2

Sec07.063 


\section{Inhoud}

Bladzijde

Voorwoord

1 Inleiding

2 Methodiek en data voor het beroepenmodel van de uitbreidingsvraag

3 Aanpassingen in het beroepenmodel voor onderwijs en zorg

4 De uitbreidingvraag naar beroep tot 2010

5 Conclusies

Referenties

Bijlage A Indeling naar bedrijfstakken, i.h.b. voor zorg en onderwijs

Bijlage B Indeling naar beroepssegmenten

Bijlage C Beroepssegmenten en -groepen in het onderwijs, volgens SBC '92

Bijlage D Beroepssegmenten en -groepen in de zorg, SBC '92

Bijlage E Prognoseresultaten voor de beroepssegmenten van het onderwijs 



\section{Voorwoord}

In dit werkdocument wordt verslag gedaan van een onderzoek naar het beroepenmodel van de uitbreidingsvraag van het ROA. Het onderzoek vindt plaats in het kader van het Project Onderwijs-Arbeidsmarkt (POA). In Cörvers en Dupuy (2006) is het beroepenmodel beschreven dat is gebruikt voor het samenstellen van de prognoses voor de uitbreidingsvraag tot 2010. Deze prognoses zijn gepubliceerd in het rapport De arbeidsmarkt naar opleiding en beroep tot 2010 (ROA, 2005), dat een overzicht biedt van de huidige en toekomstige ontwikkelingen op de Nederlandse arbeidsmarkt in de periode 2005-2010. De prognoses worden elk twee jaar herhaald voor een nieuwe periode van vijf jaar. De uitkomsten in het voorliggende document worden benut om het huidige model van de uitbreidingsvraag te verbeteren voor de beroepen in de gezondheidszorg en het onderwijs.

Het Project Onderwijs-Arbeidsmarkt wordt gefinancierd door het Ministerie van Onderwijs, Cultuur en Wetenschap (OCW), het Ministerie van Landbouw, Natuur en Voedselkwaliteit (LNV), het Centrum voor Werk en Inkomen (CWI), de vereniging kenniscentra beroepsonderwijs bedrijfsleven COLO, Randstad Nederland, de Raad voor Werk en Inkomen (RWI) en het Uitvoeringsinstituut Werknemersverzekeringen (UWV). 



\section{$1 \quad$ Inleiding}

Het beroepenmodel van de uitbreidingsvraag in het Project Onderwijs-Arbeidsmarkt (POA) dient voor het samenstellen van prognoses van de uitbreidingsvraag voor 127 beroepsgroepen. Het samenstellen van deze prognoses en de prognoses voor de vervangingsvraag, de arbeidsmarktinstroom van schoolverlaters en de discrepanties op de arbeidsmarkt gebeurt tweejaarlijks. De meest recente prognoses zijn gepubliceerd in het in november 2005 verschenen rapport De arbeidsmarkt naar opleiding en beroep tot 2010 (ROA, 2005). In de inleiding van het genoemde rapport en in het werkdocument Methodologie arbeidsmarktprognoses en -indicatoren 2005-2010 (Cörvers et al., 2006) worden overzichten gegeven van alle deelmodellen die voor het samenstellen van de arbeidsmarktprognoses gebruikt worden, de samenhang tussen deze deelmodellen, en de databronnen en externe ramingen (van o.a. CPB, CBS, OCW) waarop de arbeidsmarktprognoses zijn gebaseerd.

Het oorspronkelijke beroepenmodel van de uitbreidingsvraag is beschreven in een studie van Borghans en Heijke (1994). In deze studie worden op basis van verklarende variabelen uit het Athena-model van het Centraal Planbureau (CPB) prognoses gemaakt van de werkgelegenheidsontwikkeling naar beroep. Het Athena-model is een algemeen evenwichtsmodel met een differentiatie naar ongeveer 15 sectoren. ${ }^{1}$ Het model wordt door het CPB gebruikt om (middel)langetermijnramingen ${ }^{2}$ te maken. In de studie van Borghans en Heijke (1994) werd geconcludeerd dat de groeiprognoses van een bedrijfstak een belangrijke nevenvoorwaarde zijn voor de groei van de beroepssegmenten in de betreffende bedrijfstak. Bovendien werd het belang van de zogenaamde random-coëfficiënten-methode aangetoond voor de stabiliteit van de schattingsresultaten op basis van een relatief korte tijdreeks. Verder kwam naar voren dat de betekenis van de verklarende variabelen - buiten de trend - voor de werkgelegenheidsontwikkeling en de kwaliteit van de prognoses klein was. Aanbevolen werd om

1. In dit document worden de benamingen 'bedrijfstakken' (CPB-term) en 'sectoren' (zie ROA, 2002) door elkaar gebruikt.

2. In de loop der tijd is het model meer geschikt gemaakt voor langetermijn- dan voor middellangetermijnramingen (zie ook CPB, 2006). 
onderzoek te verrichten naar variabelen waarmee beter de werkgelegenheidsontwikkeling naar beroep verklaard en voorspeld kan worden.

In Cörvers en Dupuy (2006) wordt het belang van vier sectorvariabelen voor de werkgelegenheidsontwikkeling per beroepsgroep in een micro-economisch model onderbouwd. Bovendien worden deze variabelen in een empirisch model getoetst op hun verklaringskracht en significantie voor de werkgelegenheidsontwikkeling naar beroep. Het gaat hierbij om variabelen op sectorniveau, te weten het produktieniveau, investeringen in fysiek kapitaal en Research en Development (R\&D), en de loonsom. Met uitzondering van de investeringen in R\&D zijn voor deze sectorvariabelen prognoses beschikbaar van het CPB (gebaseerd op o.a. het Athena-model). De sectorvariabelen zijn, naast de trend van de werkgelegenheid naar beroep, gebruikt in het beroepenmodel van de uitbreidingsvraag voor het samenstellen van de arbeidsmarktprognoses zoals gepubliceerd in ROA $(2003,2005)$. Behalve voor de onderbouwing en de verbetering van de kwaliteit van de prognoses kunnen de sectorvariabelen tevens worden gebruikt om scenario-analyses uit te voeren.

In dit werkdocument staan de achtergronden en de modelspecificatie van het beroepenmodel van de uitbreidingsvraag centraal. Het gaat in het voorliggende onderzoeksverslag vooral om een analyse van de relevantie van exogene variabelen die de werkgelegenheidsontwikkeling van beroepen in de gezondheidszorg en het onderwijs kunnen verklaren. Daarbij wordt niet zo zeer ingegaan op de technische aspecten van het model (zie daarvoor Cörvers en Dupuy, 2006), als wel op de werking van het model in algemene termen en de prognoseresultaten.

Verwacht kan worden dat de eerder genoemde verklarende variabelen zoals investeringen in kapitaal en $R \& D$ vooral voor industriële sectoren van belang zijn. In de gezondheidszorg en het onderwijs zouden juist demografische variabelen een rol kunnen spelen bij de vraag naar arbeidskrachten. Door de vergrijzing stijgt het aantal ouderen waardoor de werkgelegenheid in de gezondheidszorg zal toenemen. In dit verband kan men spreken van een grijsgedreven werkgelegenheidsontwikkeling. Het Centraal Planbureau heeft in een langetermijnverkenning de werkgelegenheidsontwikkeling voor overheid en 
zorg aan de hand van vier scenario's onderzocht (Bos et al., 2004). Volgens het CPB zal het werkgelegenheidsaandeel van de zorg in de totale werkgelegenheid stijgen van 10,8\% in 2001 naar tussen de 16,4 en 18,5\% in 2040 (afhankelijk van het scenario). Daarbij speelt niet alleen de vergrijzing een belangrijke rol, maar bijvoorbeeld ook de ontwikkeling in de medische technologie en de arbeidsproductiviteitsgroei. In absolute zin is er tussen 2001 en 2040 sprake van een stijging van de werkgelegenheid in de zorg van jaarlijks 0,6 tot $1,8 \%$ (vgl. tussen $-0,5$ en $0,4 \%$ voor de totale werkgelegenheid).

Omgekeerd stagneert de vraag naar onderwijspersoneel door de ontgroening van de bevolking door het dalende aantal geboortes. Als er minder jongeren zijn gaat dat ten koste van de werkgelegenheid voor docenten in het basisonderwijs en het voortgezet onderwijs, maar op den duur ook voor docenten in het beroepsonderwijs en het hoger onderwijs. Men zou kunnen spreken van een groengeleide werkgelegenheidsontwikkeling. Daarnaast zijn er andere factoren dan de ontgroening die eveneens een rol spelen voor de werkgelegenheidsontwikkeling in het onderwijs, zoals de toestroom van jonge immigranten die recht op onderwijs hebben. Bovendien is de samenstelling van het docentenkorps binnen het totale onderwijs afhankelijk van keuzes voor bijvoorbeeld extra financiering voor speciaal onderwijs versus hoger onderwijs, of gesubsidieerd onderwijs versus particulier onderwijs. Deze keuzes komen in de scenario-analyse van het CPB tot uitdrukking. De deelname aan het onderwijs en de vraag naar leerkrachten wordt tevens beïnvloed door de doorstroom van leerlingen en studenten binnen het onderwijs (snelheid, niveau en richting) en de leerling/leraar-ratio. Afhankelijk van het betreffende CPB-scenario (Bos et al., 2004) zal het werkgelegenheidsaandeel van het gesubsidieerde onderwijs in 2040 hetzelfde zijn als in 2001, namelijk 4,8\%, of zal het werkgelegenheidsaandeel stijgen tot maximaal $5,6 \%$ van de totale werkgelegenheid in Nederland. In absolute zin is er voor de werkgelegenheidsontwikkeling in het gesubsidieerde onderwijs tussen 2001 en 2040 sprake van een lichte daling van jaarlijks $-0,2 \%$ tot een stijging van jaarlijks $0,5 \%$.

In dit werkdocument wordt een analyse gegeven van de betekenis van het toevoegen van verklarende variabelen over de demografie voor de voorspelkracht van het beroepenmodel van de uitbreidingsvraag. Het gaat 
daarbij om het effect van het aantal jongeren en ouderen op de vraag naar arbeidskrachten in het onderwijs en de zorg. Aangezien het Centraal Bureau voor de Statistiek (CBS) bevolkingsprognoses voor alle leeftijdsklassen maakt, kunnen deze prognoses als exogene variabelen in het beroepenmodel van de uitbreidingsvraag worden toegevoegd.

In paragraaf 2 wordt eerst ingegaan op het beroepenmodel van de uitbreidingsvraag zoals dit is gebruikt voor De arbeidsmarkt naar opleiding en beroep tot 2010 (ROA, 2005). Vervolgens wordt in paragraaf 3 ingegaan op de keuze voor de exogene demografische variabelen als additionele verklarende variabelen in het beroepenmodel, en worden deze variabelen aan een nadere analyse onderworpen. In paragraaf 4 worden de resultaten van de regressie-analyses van het beroepenmodel en de daaruit volgende prognoses van de uitbreidingsvraag weergegeven. In paragraaf 5 wordt afgesloten met de conclusies van het onderzoek.

\section{Methodiek en data voor het beroepenmodel van de uitbreidingsvraag}

In deze paragraaf wordt ingegaan op de achtergronden wat betreft de methodiek en de data bij het samenstellen van de middellangetermijnprognoses naar beroep. Eerst wordt kort ingegaan op de verschillende onderdelen van het totale model voor de uitbreidingsvraag, en vervolgens op het beroepenmodel en de schattingsmethode voor de uitbreidingsvraag naar beroep.

\section{Model uitbreidingsvraag}

In figuur 2.1 is aangegeven hoe de prognoses van de werkgelegenheidsontwikkeling voor beroepen en opleidingen tot stand komen. Uit de figuur blijkt tevens hoe de verschillende modellen van de uitbreidingsvraag met elkaar samenhangen en waar de interactie met de aanbodzijde van de arbeidsmarkt optreedt. De werkgelegenheidsprognoses per bedrijfstak zijn de belangrijkste bron voor de uitbreidingsvraag naar beroep en worden gepubliceerd door het Centraal Planbureau (CPB). Het CPB gebruikt voor het samenstellen van deze 
(middel)langetermijnramingen van de werkgelegenheid het zogenaamde Athena-model (CPB, 1990, 2006).

In het beroepenmodel wordt de voorspelde werkgelegenheidsontwikkeling per bedrijfstak omgezet naar de werkgelegenheidsontwikkeling per beroepssegment. Hierbij wordt de veronderstelling gemaakt dat de werkgelegenheid naar beroep volledig door de vraagzijde van de arbeidsmarkt bepaald wordt. De ontwikkelingen in de vraag naar beroep worden bepaald door de werkgelegenheidsverschuivingen tussen bedrijfstakken en de veranderingen in de beroepenstructuur van de werkgelegenheid per bedrijfstak.

Vervolgens vindt er vanuit de prognoses van de uitbreidingsvraag per beroepssegment een verdere uitsplitsing plaats naar de beroepsgroepen. De beroepenindeling is gebaseerd op de Standaard Beroepen Classificatie uit 1992 (SBC '92) van het CBS (1993). De beroepssegmenten zijn gebaseerd op de indeling op 2-digit-niveau; de beroepsgroepen op de indeling op 3-digit-niveau. Er worden in totaal 43 beroepssegmenten en 127 beroepsgroepen onderscheiden. ${ }^{3}$

De prognoses van de uitbreidingsvraag per beroepssegment vormen ook de basis voor de prognoses van de uitbreidingsvraag per opleidingstype. In het opleidingenmodel vindt een confrontatie plaats tussen vraag en aanbod, waardoor ook de invloeden op de vraag die veroorzaakt worden door overschotten of tekorten in aanverwante studierichtingen in het model kunnen worden opgenomen. Hiervoor zijn de prognoses van de arbeidsmarktinstroom van schoolverlaters en de vervangingsvraag en de informatie over de kortdurige werkloosheid per opleidingstype aan het begin van de prognoseperiode noodzakelijke invoergegevens voor het model.

3. Zie de 2-digit- en 3-digit-codes en de bijbehorende benamingen in tabel 6 en 7 van de ROA-classificatiegids (ROA, 2002). 
Figuur 2.1

Overzicht van de totstandkoming van de prognoses van de uitbreidingsvraag naar beroep en opleiding

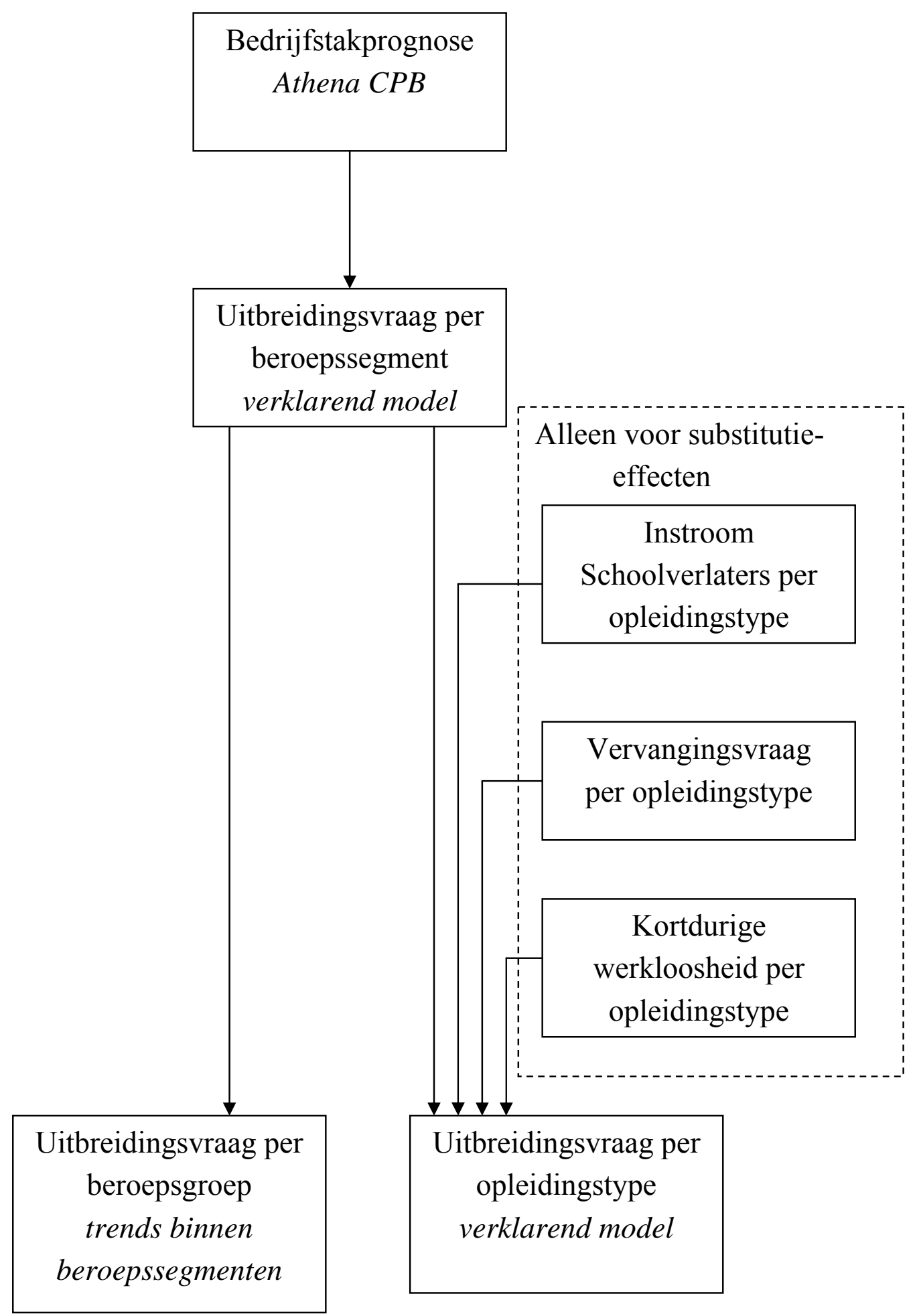


Het beroepenmodel van de uitbreidingsvraag heeft betrekking op de uitbreidingsvraag per beroepssegment (zie figuur 2.1). Bij de modellering is nagegaan welke variabelen in aanmerking zouden kunnen komen ter verklaring van de beroepenstructuur binnen bedrijfstakken. Bij de selectie van deze verklarende variabelen is rekening gehouden met de volgende criteria:

- Het gebruik van de verklarende variabelen moest theoretisch onderbouwd kunnen worden;

- Er dienden voor deze variabelen voldoende lange tijdreeksen beschikbaar te zijn;

- Er dienden tevens prognoses van deze variabelen beschikbaar te zijn;

- De verklarende variabelen moesten voldoende voorspelkracht hebben en plausibele resultaten opleveren.

In Cörvers en Dupuy (2006) wordt het belang van vier variabelen voor de werkgelegenheidsontwikkeling van beroepen in sectoren in een microeconomisch model onderbouwd. In dit model spelen, behalve de tijdtrend, vier factoren een rol bij de verklaring van de veranderingen in de vraag naar beroepen binnen bedrijfstakken:

- Het productieniveau per bedrijfstak ('non-homothetic production function');

- De kapitaalintensiteit per bedrijfstak ('capital-skill complementarity');

- Het gebruik van nieuwe meer kennisintensieve technologieën ('skill biased technological change') in elke bedrijfstak;

- De relatieve lonen op de verschillende arbeidsmarktsegmenten.

\section{Data-input}

De uitbreidingsvraag naar beroep is geschat met EBB-data van 1988 tot en met 2003. Het gaat bij deze werkgelegenheidscijfers om werkzame personen die voor minstens 12 uren per week werk hebben. In de EBB-matrices beroepssegment $\mathrm{x}$ sector zijn de aantallen beneden de door het CBS vereiste ondergrens gelijkgesteld aan 0. Hierdoor verdwijnen in iedere sector een aantal kleinere beroepssegmenten. Beroepssegmenten die voor één of meerdere jaren niet 
voorkomen in de tijdreeks zijn weggelaten. In totaal is de werkgelegenheidsontwikkeling geschat voor 195 combinaties van beroepssegmenten en sectoren.

Het CBS is vanaf 1994 over gegaan op een nieuwe sectorindeling. Om toch de EBB gegevens voor de periode 1988 tot en met 1993 te kunnen gebruiken is een schatting gemaakt van aantallen werkenden per sector volgens de nieuwe indeling. Dit was mogelijk omdat in 1994 zowel de oude als de nieuwe classificatie gehanteerd zijn. De verhoudingen van de aantallen werkenden per beroepssegment per sector volgens de oude en nieuwe indeling in dat jaar zijn dus bekend. Voorts heeft het CBS vanaf 1996 een nieuwe reeks van EBBbestanden met vergelijkbare classificaties en dataverzameling samengesteld. Vanwege de bovenstaande twee aanpassingen is gekeken naar breuken in de tijdreeksen voor de jaren tussen 1994 en 1996. Dit heeft ertoe geleid dat voor 19 van de 195 combinaties van sector en beroep dummy-variabelen zijn opgenomen in de schattingsvergelijkingen.

Wat betreft de verklarende variabelen zijn er voor de 13 verschillende bedrijfstakken data verzameld over de toegevoegde waarde tussen 1988 en 2003, en over de investeringen in kapitaal en in Research and Development (R\&D) tussen 1970 en 2003. ${ }^{4}$ De benodigde data zijn ontleend aan de zogenaamde 'Lange Reeksen' van het CPB. Deze reeksen zijn gebaseerd op de Nationale Rekeningen van het CBS, en worden door het CPB gebruikt als datainput voor de schattingen van de vergelijkingen in het Athena-model. Alleen de R\&D-gegevens zijn direct afkomstig van het CBS (via Statline), en zijn gebaseerd op de R\&D- en innovatie-enquêtes van het CBS onder bedrijven, research-instellingen en universiteiten. De investeringen in kapitaal en $R \& D$ zijn omgerekend naar voorraadgrootheden volgens de algemeen gebruikte Perpetual Inventory Method (PIM). De gehanteerde afschrijvingspercentages zijn $8 \%$ voor kapitaal en $15 \%$ voor R\&D.

4. Een vierde verklarende variabele, de loonsom per sector, bleek sterk gecorreleerd te zijn aan de toegevoegde waarde en is daarom niet meegenomen in het definitieve schattingsmodel. 
In het schattingsmodel (zie hieronder) worden prognoses gemaakt van de werkgelegenheidsaandelen van beroepssegmenten binnen sectoren. Startpunt zijn de sectorale werkgelegenheidsprognoses van het Centraal Planbureau (CPB). De prognoses van de uitbreidingsvraag tot 2010 zijn deels gebaseerd op een scenario-analyse van het CPB $(2004,2005)$. De vier scenario's van het CPB hebben betrekking op de lange termijn (tot 2020 en 2040), waarbij het Athenamodel een belangrijk hulpmiddel was. Voor de prognoses van de uitbreidingsvraag wordt uitgegaan van één van de twee middenscenario's van het $\mathrm{CPB}$, te weten 'Transatlantic Market' (TM), dat gegeven de ontwikkelingen tot 2005 het meest realistisch werd geacht.

In afwijking van deze langetermijnramingen is voor de sectorprognoses van de uitbreidingsvraag voor 2005 en 2006 gebruik gemaakt van het Centraal Economisch Plan 2005 (CEP) van het CPB (2005a). Door het gebruik van deze kortetermijnprognoses worden de gehanteerde langetermijnramingen gecorrigeerd met de meer recente inzichten in de groeiverwachtingen volgens het CEP. Verder is bij het bepalen van de sectorprognoses van de uitbreidingsvraag tot 2010 verondersteld dat de sectorale werkgelegenheid op de lange termijn (in 2020) uitkomt op het niveau dat volgens het TM-scenario wordt bereikt. Omdat het CPB de kortetermijnprognoses niet meer zoals voorheen volledig differentieert naar de ongeveer 15 sectoren volgens de Athena-indeling, is tevens gebruik gemaakt van de verdere differentiatie van de kortetermijnprognoses van het CPB door het EIM (2005).

De sectorale werkgelegenheidsprognoses van CPB en EIM zijn arbeidsvolumeprognoses, welke aan de hand van prognoses van P/A-ratio's (i.e. verhouding tussen personen en arbeidsjaren) worden omgerekend naar prognoses van het aantal werkzame personen per bedrijfstak (EIM, 2005). Voor de jaren na 2006 zijn de P/A-ratio's geëxtrapoleerd.

De prognoses voor de drie verklarende variabelen in het beroepenmodel zijn op verschillende manieren tot stand gekomen. Voor de toegevoegde waarde zijn zowel de korte- als de langetermijnprognoses tot 2010 op eenzelfde manier bepaald als voor de sectorale werkgelegenheid. Wat betreft de investeringen in kapitaal is voor 2005 en 2006 gebruik gemaakt van de kortetermijnprognoses 
van het CPB (2005a) en het EIM (2005). Omdat langetermijnramingen van de investeringen in kapitaal voor de jaren na 2006 niet direct beschikbaar waren, is voor deze jaren 'double exponential smoothing' toegepast. Voor de investeringen in $R \& D$ waren geen prognoses beschikbaar. Deze zijn gebaseerd op een extrapolatie met 'double exponential smoothing' van de tijdreeksen van het CBS.

\section{Schattingsmethode}

In de eerste stap van de schattingsprocedure is getoetst of de verschillende tijdreeksen (1988-2003) al dan niet stationair zijn, dat wil zeggen er is gekeken naar de significantie van een stochastische of deterministische trend in de werkgelegenheidsontwikkeling van de beroepssegmenten per sector en de bovengenoemde vier verklarende variabelen. De 'unit root'-testen wijzen uit dat er bijna altijd sprake is van een stochastische trend. Tevens is er in meer dan driekwart van de tijdreeksen een significante deterministische trend. Uit de resultaten van de empirische toetsing kan geconcludeerd worden dat alle tijdreeksen non-stationair en geïntegreerd van de eerste orde zijn. Derhalve wordt er getoetst of er sprake is van coïntegratie tussen de werkgelegenheidsaandelen van beroepssegmenten per sector en de verklarende sectorvariabelen.

In de test op coïntegratie wordt gekeken naar de afwijking van het aandeel van de werkgelegenheid van een beroepssegment in een sector van het geschatte langetermijnverband (zie de 'error correction' term in vgl. 4.1). Het blijkt dat de residuen stationair zijn voor meer dan driekwart van de combinaties van beroepssegment en sector. Voor de werkgelegenheidsaandelen van beroepssegment $j$ in sector $i$, weergegeven door $l_{i j, t}$, worden daarom aan de hand van de betreffende tijdreeksen van 1988-2003 (t) de volgende vergelijkingen geschat volgens de 'error correction' specificatie zoals voorgesteld door Engle en Granger (1987):

$$
\Delta l_{i j, t}=\alpha_{i j}+\sum_{k} \lambda_{k i j} \Delta x_{k i, t}+\gamma_{i j} \sum_{k}\left(l_{i j, t-1}-\beta_{k i j} x_{k i, t-1}\right)+\varepsilon_{i j, t}^{*}
$$


waarbij $x_{k i, t}$ de verklarende variabelen $k$ per sector $i$ representeren, en $\varepsilon_{i j, t}^{*}$ is een storingsterm. $\alpha_{i j}$ en $\lambda_{k j}$ zijn de parameters voor respectievelijk de constante en de $k$ verklarende variabelen $(k=3)$. Bovendien geven de parameters $\gamma_{i j}$ en $\beta_{k i j}$ de effecten weer van de afwijkingen van het langetermijnevenwicht (de 'error correction') en de verklarende variabelen $k$ op de werkgelegenheidsaandelen van beroepssegment $j$ in sector $i$. Het 'error correction' mechanisme is in ongeveer $95 \%$ van de combinaties van sectoren en beroepssegmenten statistisch significant. In afwijking van de prognosemethodiek van twee jaar geleden (zie Cörvers et al., 2004) is de bovenstaande specificatie aangepast door in de storingstermen ook rekening te houden met intertemporele correlaties tussen combinaties van sectoren en beroepssegmenten. Deze techniek staat bekend als de zogenaamde Dynamic OLS (Mark et al., 2003). Bovendien zijn de verschillende schattingsvergelijkingen 'gepoold', waarbij 'fixed effects' voor de sectoren en de beroepssegmenten zijn opgenomen. Dit laatste verlaagt de variantie van de geschatte parameters doordat het aantal vrijheidsgraden aanzienlijk toeneemt (zie verder Cörvers en Dupuy, 2006).

De aggregatie over dezelfde beroepssegmenten binnen de verschillende bedrijfstakken resulteert in de prognoses van de uitbreidingsvraag per beroepssegment. Vervolgens zijn de prognoses per beroepssegment verbijzonderd naar beroepsgroepen. Om stabiele parameterschattingen te krijgen zonder daarbij de specificiteit van de afzonderlijke beroepen aan te tasten is gebruik gemaakt van een random-coëfficiënten-model. ${ }^{5}$ De werkgelegenheidsgroei per beroepsgroep wordt daarbij geschat als afwijking van de totale groei van het beroepssegment waar de betreffende beroepsgroep onder valt (zie verder Cörvers et al., 2006).

\section{Aanpassingen in het beroepenmodel voor onderwijs en zorg}

In deze paragraaf wordt eerst ingegaan op beperkingen die er waren bij de keuze voor exogene verklarende variabelen om het beroepenmodel voor het onderwijs en de zorg te verbeteren. Vervolgens wordt ingegaan op de relatie tussen sec-

5. Borghans en Heijke (1994) geven een uitvoerige beschrijving van dit model. 
toren en de beroepen die met onderwijs en zorg te maken hebben. Tot slot worden de correlaties en modelschattingen gepresenteerd op basis van de tijdreeksen die bij het samenstellen van de prognoses in 2005 beschikbaar waren. Daarbij is gekeken naar de relevantie van demografische variabelen voor de beroepen in het onderwijs en de gezondheidszorg.

\section{Beperkingen}

Bij de keuze van verklarende variabelen die relevant kunnen zijn voor de vraag naar arbeidskrachten in het onderwijs en de zorg is er een aantal beperkingen. Een eerste beperking houdt verband met de door ons zelf opgelegde keuze om vast te houden aan de grote lijnen van het model dat is uiteengezet in de vorige paragraaf. Dat betekent onder meer dat de sectorramingen van de werkgelegenheid van het CPB een randtotaal zijn voor de prognoses van de uitbreidingsvraag naar beroep.

Een tweede beperking is dat er beschikt moet kunnen worden over prognoses van de verklarende variabelen om de werkgelegenheid naar beroep te voorspellen. Uit de voorgaande paragraaf werd duidelijk dat er voor de toegevoegde waarde en de investeringen in kapitaal sectorvoorspellingen worden gedaan door het CPB en EIM. Voor de investeringen in R\&D is dat niet het geval, en is de prognose van R\&D-kennisvoorraad gebaseerd op een extrapolatie van de R\&D-investeringen.

Een derde beperking is dat de sectordifferentiatie volgens het Athena-model min of meer gegeven is ${ }^{6}$, waardoor een verdere differentiatie naar subsectoren binnen overheid en onderwijs of binnen de gezondheidszorg niet zonder meer mogelijk is. De verklarende variabelen die aan het beroepenmodel van de uitbreidingsvraag toegevoegd worden kunnen uitsluitend invloed hebben op verschuivingen van beroepssegmenten binnen deze sectoren. Overigens komen de sectorclassificaties die het CPB en CBS hanteert (gebaseerd op SBI '93) op veel punten niet overeen met de institutionele indelingen (vaak volgens CAO's) die bij het Rijk gebruikelijk zijn.

6. Er bestaat alleen de mogelijkheid om sectoren te aggregeren. Zie bijlage A voor de huidige sectordifferentiatie. 
Een vierde beperking is dat ook de indeling naar beroepssegmenten (2-digitindeling) in het voorliggende onderzoek als gegeven is beschouwd. Deze indeling is gebaseerd op de Standaard Beroepen Classificatie (SBC '92) van het CBS (zie Bijlage B). Uit de vorige paragraaf werd duidelijk dat prognoses van de uitbreidingsvraag naar beroep worden samengesteld aan de hand van tijdreeksen van de werkgelegenheid van beroepssegmenten binnen sectoren. Indien de beroepssegmenten verder uitgesplitst worden, bijvoorbeeld naar een 3-digitindeling, levert dat in veel gevallen te kleine combinaties van sector $\mathrm{x}$ beroep op, dat wil zeggen te klein gegeven de steekproefomvang van de Enquête Beroepsbevolking (EBB) en de daarbij behorende ondergrenzen.

Een vijfde beperking is dat het voor de beroepssegmenten in Bijlage B binnen zowel het onderwijs als de zorg niet direct duidelijk is hoe de grijsgedreven of groengeleide vraag naar arbeidskrachten in deze beroepssegmenten gekoppeld is aan de bevolkingsgroei van de verschillende leeftijdklassen van jongeren en ouderen. Op deze laatste beperking wordt verderop in deze paragraaf nog ingegaan.

\section{Sector- en beroepenclassificaties voor onderwijs en zorg}

Eerst is gekeken naar hoe de beroepssegmenten en -groepen aan elkaar en aan het onderwijs en de zorg gerelateerd zijn. Daartoe is in Bijlage C en D het verband tussen beroepssegmenten (2-digit-indeling SBC '92) en beroepsgroepen (3-digit-indeling SBC '92) weergegeven voor beroepen die gerelateerd zijn aan het onderwijs en de zorg. Er blijkt dat de indeling naar beroepssegmenten van een redelijk hoog aggregatieniveau is. Zo worden in het beroepenmodel bijvoorbeeld leerkrachten basisonderwijs samengevoegd met docenten $2 \mathrm{e}$ en $3 \mathrm{e}$ graads die in het voortgezet onderwijs (onderbouw) kunnen werken. Voor de beroepsgroepen gericht op het onderwijs is veelal niet duidelijk aan welke subsectoren deze beroepsgroepen gekoppeld zijn, bijvoorbeeld voortgezet onderwijs of hoger onderwijs. Wel wordt er onderscheid gemaakt in de bevoegdheid van docenten (WO en 1e graads, versus $2 \mathrm{e}$ en $3 \mathrm{e}$ graads). Sommige beroepsgroepen gericht op de zorg lijken meer in de commerciële dienstverlening dan in de gezondheidszorg thuis te horen (bijv. café- en snackbarhouders), en ook hier is de koppeling aan subsectoren in de zorg (bijv. ziekenhuizen of welzijnsinstellingen) niet onmiddellijk duidelijk. 
Tabel 3.1

Uitwijkmogelijkheden naar bedrijfssector* van onderwijs- en zorggerelateerde beroepsgroepen, en het percentage werkenden van deze beroepsgroepen dat in het onderwijs en de gezondheidszorg werkzaam is**, gem. 2003-2004

\begin{tabular}{|c|c|c|c|c|c|c|}
\hline \multicolumn{2}{|c|}{ ROA-nr. } & \multicolumn{3}{|c|}{ Spreiding* over sectoren } & \multirow[t]{2}{*}{$\begin{array}{c}\text { Onder- } \\
\text { wijs } \\
\\
\%\end{array}$} & \multirow[t]{2}{*}{$\begin{array}{l}\text { Gezond- } \\
\text { heids- } \\
\text { zorg } \\
\%\end{array}$} \\
\hline Segr & nent & Nummer en naam beroepsgroep & Indicator & Typering & & \\
\hline \multicolumn{7}{|c|}{ Onderwijs } \\
\hline 3 & 17 & Zweminstructeurs & 2,21 & gemiddeld & $\star \star \star *$ & $\star \star \star *$ \\
\hline 12 & 16 & Rij-instructeurs & 1,52 & laag & 81 & - \\
\hline 12 & 18 & Sportinstructeurs & 2,54 & gemiddeld & $\star * *$ & $\star \star * *$ \\
\hline 23 & 1 & \multirow{2}{*}{$\begin{array}{l}\text { Leraren basisonderwijs } \\
\text { Docenten exacte, medische en verzorgende } \\
\text { vakken ( } P \text { ค ค } 3 \rho \mathrm{rr} \text { ) }\end{array}$} & 1,09 & erg laag & 95 & - \\
\hline 23 & 2 & & 1,24 & laag & 89 & 8 \\
\hline 23 & 4 & \multirow{2}{*}{$\begin{array}{l}\text { Docenten landbouw en techniek ( } 2 \mathrm{e} \text { en } 3 \mathrm{e} \text { gr.) } \\
\text { Docenten economisch-administratieve vakken ( } 2 \mathrm{e} \\
\text { en } 3 \mathrm{e} \text { rr I }\end{array}$} & 1,45 & laag & 82 & - \\
\hline 23 & 6 & & 1,38 & laag & 84 & - \\
\hline 23 & 8 & Docenten talen en expressie & 1,48 & laag & 78 & - \\
\hline 23 & 10 & Docenten sociale vakken (2e en 3e gr.) & 1,20 & laag & 91 & - \\
\hline 23 & 12 & Docenten $2 \mathrm{e}$ en $3 \mathrm{e}$ graads zonder specialisatie & 1,12 & laag & 94 & - \\
\hline 23 & 14 & \multirow{2}{*}{$\begin{array}{l}\text { Onderwijskundig medewerkers } \\
\text { Docenten exacte, medische en verzorgende } \\
\text { vakkan (1ค ar an } w / \cap)\end{array}$} & 2,68 & gemiddeld & 56 & - \\
\hline 35 & 3 & & 1,23 & laag & 89 & 8 \\
\hline 35 & 5 & \multirow{2}{*}{$\begin{array}{l}\text { Docenten landbouw en techniek (1e gr. en WO) } \\
\text { Docenten economisch-administratieve vakken (1e } \\
\text { or en W/n) }\end{array}$} & 1,11 & erg laag & 95 & - \\
\hline 35 & 7 & & 1,09 & erg laag & 96 & - \\
\hline 35 & 9 & Docenten letteren (1e gr. en WO) & 1,07 & erg laag & 97 & - \\
\hline 35 & 11 & Docenten sociale vakken (1e gr. en WO) & 1,10 & erg laag & 94 & - \\
\hline 35 & 13 & Docenten 1 e graads zonder specialisatie & 1,00 & erg laag & - & - \\
\hline 35 & 15 & Onderwijskundigen en pedagogen & 3,29 & gemiddeld & 33 & 40 \\
\hline \multicolumn{7}{|c|}{ Zorg } \\
\hline 11 & 74 & Verpleeghulpen en leerling-verpleegkundigen & 1,08 & erg laag & - & 96 \\
\hline 11 & 118 & Hulpkrachten horeca en verzorging & 2,72 & gemiddeld & - & 46 \\
\hline 11 & 121 & Café- en snackbarhouders & 1,71 & laag & $\star \star \star \star ~$ & 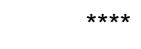 \\
\hline 17 & 75 & Verplegenden en doktersassistenten & 1,09 & erg laag & - & 95 \\
\hline 17 & 78 & Apothekersassistenten en medisch laboranten & 2,75 & gemiddeld & - & 35 \\
\hline 17 & 104 & Medisch secretaresses & 1,10 & erg laag & - & 95 \\
\hline 17 & 119 & Ziekenverzorgenden & 1,04 & erg laag & - & 97 \\
\hline 22 & 120 & Verzorgend personeel & 2,32 & gemiddeld & - & 60 \\
\hline 22 & 122 & Bedrijfshoofden horeca & 1,69 & laag & 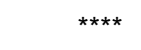 & 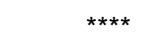 \\
\hline
\end{tabular}


Tabel 3.1 (vervolg)

Uitwijkmogelijkheden naar bedrijfssector* van onderwijs- en zorggerelateerde beroepsgroepen, en het percentage werkenden van deze beroepsgroepen dat in het onderwijs en de gezondheidszorg werkzaam is ${ }^{\star \star}$, gem. 2003-2004

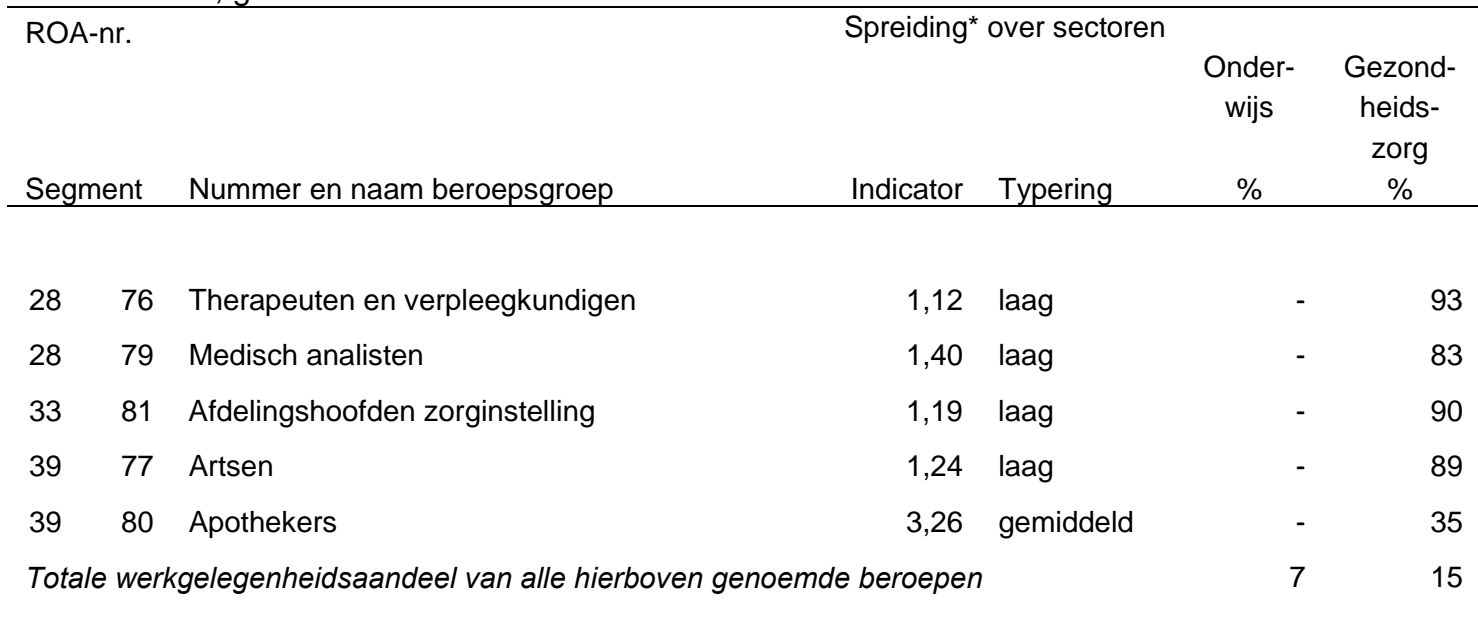

Bron: ROA/CBS

Opmerkingen:

* De spreidingsindicator geeft aan in hoeverre arbeidskrachten afhankelijk zijn van de arbeidsmarktsituatie in een bepaalde bedrijfssector, een genormeerd aantal bedrijfssectoren waarin mensen met dit opleidingstype/beroepsgroep werkzaam zijn.

** Een '-' duidt op een werkgelegenheidsaandeel van minder dan $5 \%$ of waarover het aantal onder de ondergrens van het CBS uitkwam.

*** Ongeveer $60 \%$ werkt in de overige commerciële dienstverlening.

**** Ongeveer drie kwart werkt in de sector horeca.

Ten opzichte van andere segmenten op de arbeidsmarkt is de relatie tussen de onderwijs- en zorgsectoren enerzijds en de beroepen die in deze sectoren voorkomen vrij hecht. Dit is terug te zien in tabel 3.1. In de eerste kolom van de tabel wordt het segmentnummer (ROA nr.) weergegeven van de 2-digit beroepssegmenten van het CBS (SBC '92). In de tweede en derde kolom staan het ROA-nummer en de ROA-naam van de beroepsgroepen die aan de beroepssegmenten zijn gekoppeld. Zie voor de namen van de beroepssegmenten tabel 3.2 en de Bijlage B. In de derde kolom staat de spreidingsindicator, welke samen met het percentage van een beroepsgroep werkzaam in het onderwijs en de zorg een indruk geeft van de koppeling van de beroepsgroepen met de dienstverlening in het onderwijs of de zorg.

Uit tabel 3.1 kan worden geconcludeerd dat ook voor het onderwijs en de zorg er weliswaar geen één-op-één relatie is tussen beroepsgroepen en sectoren, maar dat de relatie toch vrij hecht is. Deze conclusie wordt ook onderbouwd met de gegevens uit tabel 3.2, waaruit blijkt dat de beroepsgroepen gericht op het 
onderwijs respectievelijk de gezondheidszorg het grootste aandeel hebben in de werkgelegenheid van deze sectoren. Toch komen er ook andere beroepsgroepen voor die niet direct aan de dienstverlening in deze sectoren zijn gerelateerd, zoals boekhouders en secretaresses en interieurverzorgers.

Verder blijkt uit de tabellen 3.1 en 3.2 dat de beroepsgroepen café- en snackbarhouders en bedrijfshoofden horeca duidelijk niet thuis horen in de zorg of het onderwijs. Dit geldt in mindere mate voor de beroepsgroepen zweminstructeurs en sportinstructeurs, die wel een duidelijk pedagogisch karakter hebben. In de indeling van de beroepssegmenten zijn de genoemde beroepsgroepen (met uitzondering van de zweminstructeurs) met andere beroepsgroepen die wel aan het onderwijs of de zorg zijn gerelateerd, geaggregeerd tot de beroepssegment-indeling op 2-digit-niveau. In het beroepenmodel van de uitbreidingsvraag wordt deze indeling naar beroepssegmenten gebruikt. Ook de sectorindeling in het beroepenmodel is afwijkend van de meer uitgebreide indeling naar 34 sectoren (zie ROA, 2002) die in tabellen 3.1 en 3.2 voor onderwijs en gezondheidszorg is gebruikt. Uit Bijlage A blijkt dat de sector 'onderwijs' (34-indeling) thuis hoort in de bedrijfstak 'overheid en onderwijs' (de 13indeling), en de bedrijfssector 'gezondheidszorg' (34-indeling) thuis hoort in de bedrijfsstak 'kwartaire diensten' (13-indeling).

De redenen voor de aggregatie naar 43 beroepssegmenten en 13 bedrijfstakken zijn tweeledig. Ten eerste is er voor het beroepenmodel van de uitbreidingsvraag een combinatie van de indelingen naar sector en beroep nodig, en daarvoor zouden er gezien de beperkte steekproefomvang van de EBB bij een vergaande differentiatie te veel cellen in de matrix sector $\mathrm{x}$ beroep slecht gevuld zijn. Ten tweede worden de sectorprognoses van het CPB samengesteld op het niveau van de 13 bedrijfstakken in plaats van de 34 sectoren.

Wat dat laatste betreft is er mogelijk wel enige vooruitgang te boeken in het prognosemodel. Bij het samenstellen van de nieuwe tijdreeksen kan rekening worden gehouden met wijzigingen in de sectorindeling van het CPB (volgens Athena-model) die in de loop der tijd zijn doorgevoerd. Bovendien zouden er tijdreeksen vanaf 1988 op basis van een aangepaste classificatie van de 2-digitindeling van het CBS (de 43-indeling naar beroepssegmenten) kunnen worden 
samengesteld. Dit is met name interessant als een andere clustering van beroepsgroepen tot betere resultaten zou leiden dan de 2-digit- indeling van beroepssegmenten die in dit werkdocument gebruikt wordt.

Tabel 3.2

Overzicht van het werkgelegenheidsaandeel van beroepsgroepen in het onderwijs en de gezondheidszorg, gem. 2003-2004

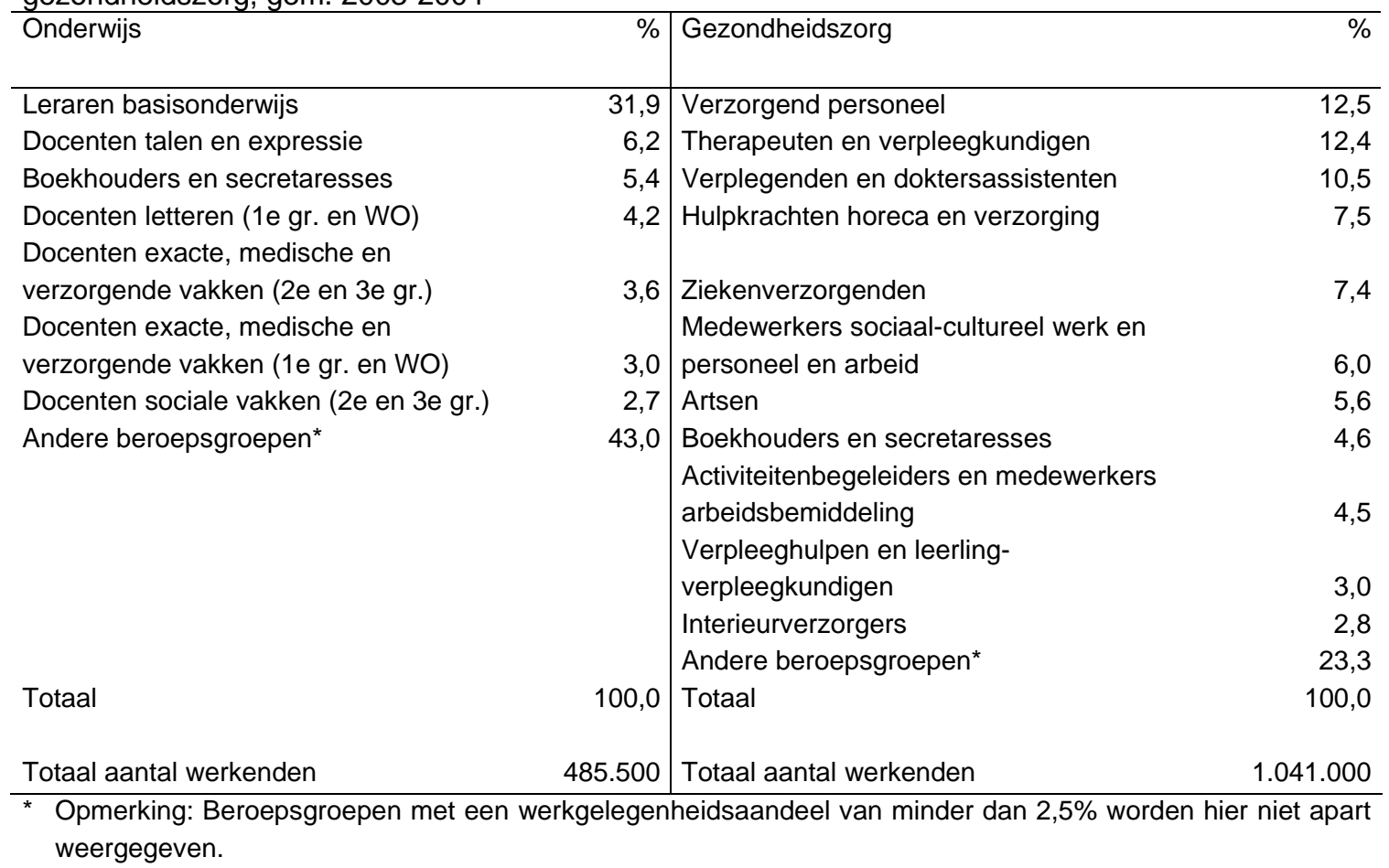

Bron: ROA/CBS

In vervolg op het bovenstaande zou ook gekeken kunnen worden naar de relatie tussen de beroepsgroepen in tabel 3.1 en de subsectoren binnen het onderwijs en de gezondheidszorg (zie Bijlage A), waardoor de relatie tussen de beroepsgroepen/segmenten en de zorgsector (bijv. welzijn of gezondheidszorg) en onderwijssector (bijv. voortgezet of hoger onderwijs) duidelijker wordt.

\section{Demografische ontwikkelingen als verklarende variabelen}

Voor de werkgelegenheidsontwikkeling van sommige beroepsgroepen in de zorg of het onderwijs kan op voorhand een sterke relatie worden vermoed tussen de werkgelegenheidsontwikkeling en de bevolkingsgroei van een leeftijdsklasse. Voor bijvoorbeeld de vraag naar leerkrachten basisonderwijs mag verwacht worden dat het aantal leerlingen op de basisscholen en dus het 
aantal leerlingen van 4 tot 11 jaar oud van groot belang is. In figuur 3.1 is zowel de historische als de verwachte ontwikkeling van het aantal 4-11 jarigen en het aantal leerlingen in de basisschool weergegeven. De gegevens zijn gebaseerd op tellingen en bevolkings- en leerlingenprognoses van het CBS (zie Statline) en het Ministerie van OCW (OCW, 2006). Uit de figuur blijkt dat het aantal leerlingen in het basisonderwijs zich op dezelfde wijze ontwikkelt als het aantal 4-11 jarigen. De 4-11 jarigen overtreft het aantal leerlingen in het basisonderwijs omdat een deel van deze groep in het speciaal basisonderwijs terecht komt. Ook de prognoses in de meest recente Referentieraming (RR2006) van het Ministerie van OCW (OCW, 2006) komen overeen met de bevolkingsprognoses voor de leeftijdsklasse van 4-11 jarigen van het CBS. Uit de figuur is verder af te lezen dat het aantal 4-11 jarigen halverwege 2005 en 2010 een maximum bereikt, om vooral vanaf 2010 sterk te dalen. Dit betekent dat een nieuwe ontgroeningsgolf voor wat betreft de 4-11 jarigen nog een paar jaar op zich laat wachten. Uit de figuur kan tevens afgeleid worden dat OCW verwacht dat het aandeel leerlingen in het speciaal onderwijs in de toekomst weer zal dalen.

In figuur 3.2 is de historische en de verwachte ontwikkeling van het aantal 1216 jarigen en het aantal leerlingen in het voortgezet onderwijs (VMBO/HAVO/VWO) weergegeven. Ook deze gegevens zijn gebaseerd op de eerder vermelde tellingen en prognoses van CBS en OCW. Aan het begin van de reeks overtreft het aantal 12-16 jarigen nog het aantal leerlingen in het voortgezet onderwijs. Dit heeft ermee te maken dat ook oudere leerlingen kunnen deelnemen aan het voortgezet onderwijs. Doordat de doorstroom is verbeterd en doordat steeds meer 12-16 jarigen in het voortgezet speciaal onderwijs terecht zijn gekomen, daalt vervolgens de verhouding tussen het aantal leerlingen in het voortgezet onderwijs en het aantal 12-16 jarigen. Uit figuur 3.2 blijkt dat het maximum aantal jongeren in de leeftijdsklasse van 12 tot 16 jaar vlak voor 2015 wordt bereikt. Dit geldt tevens voor het aantal leerlingen in het voortgezet onderwijs. $\mathrm{Na} 2015$ neemt het aantal 12-16 jarigen sterk af. Dan heeft de eerder genoemde 'ontgroeningsgolf' voor 4-11 jarigen ook deze leeftijdsgroep bereikt. 
Figuur 3.1

Ontwikkeling van het aantal leerlingen basisonderwijs en het aantal 4-11 jarigen

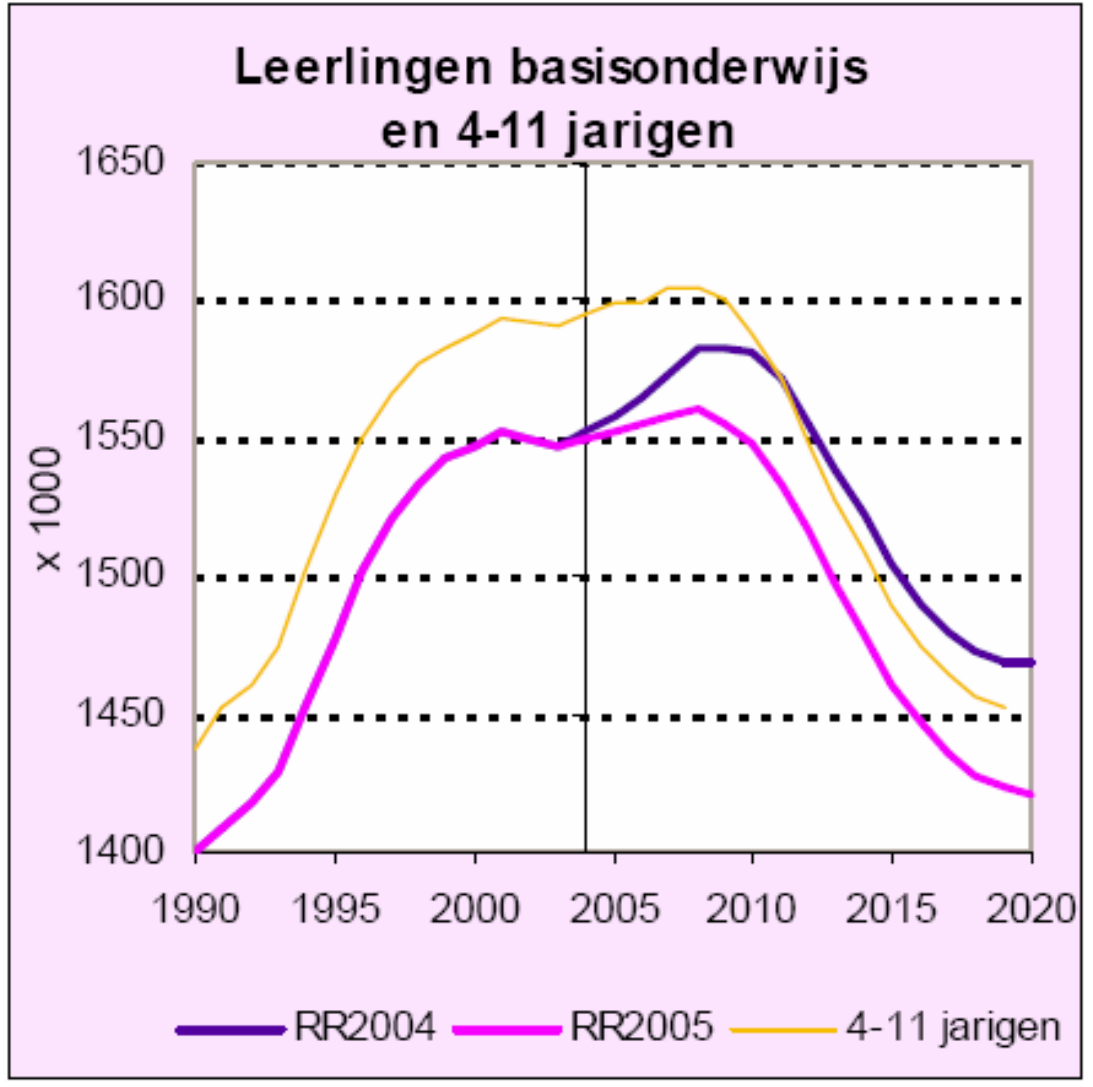

Bron: OCW (2006)

Zoals gezegd is er voor de werkgelegenheid voor de beroepssegmenten in het onderwijs en de zorg niet eenduidig aan te geven in hoeverre ze door de bevolkingsgroei van specifieke leeftijdsklassen of onderwijssoorten worden bepaald. Ten eerste zijn de beroepssegmenten daarvoor te geaggregeerd (2-digit SBC '92) wat betreft de samenstelling naar beroep. Ten tweede is de koppeling tussen onderwijs- en zorgsectoren en beroepen niet eenduidig. Daardoor is het zelfs op het aggregatieniveau van beroepsgroepen (3-digit SBC '92) moeilijk om de werkgelegenheidsontwikkeling in verband te brengen met het onderwijs of de zorg voor categorieën jongeren en ouderen in de bevolking. 
Figuur 3.2

Ontwikkeling van het aantal leerlingen voortgezet onderwijs en het aantal 12-16 jarigen

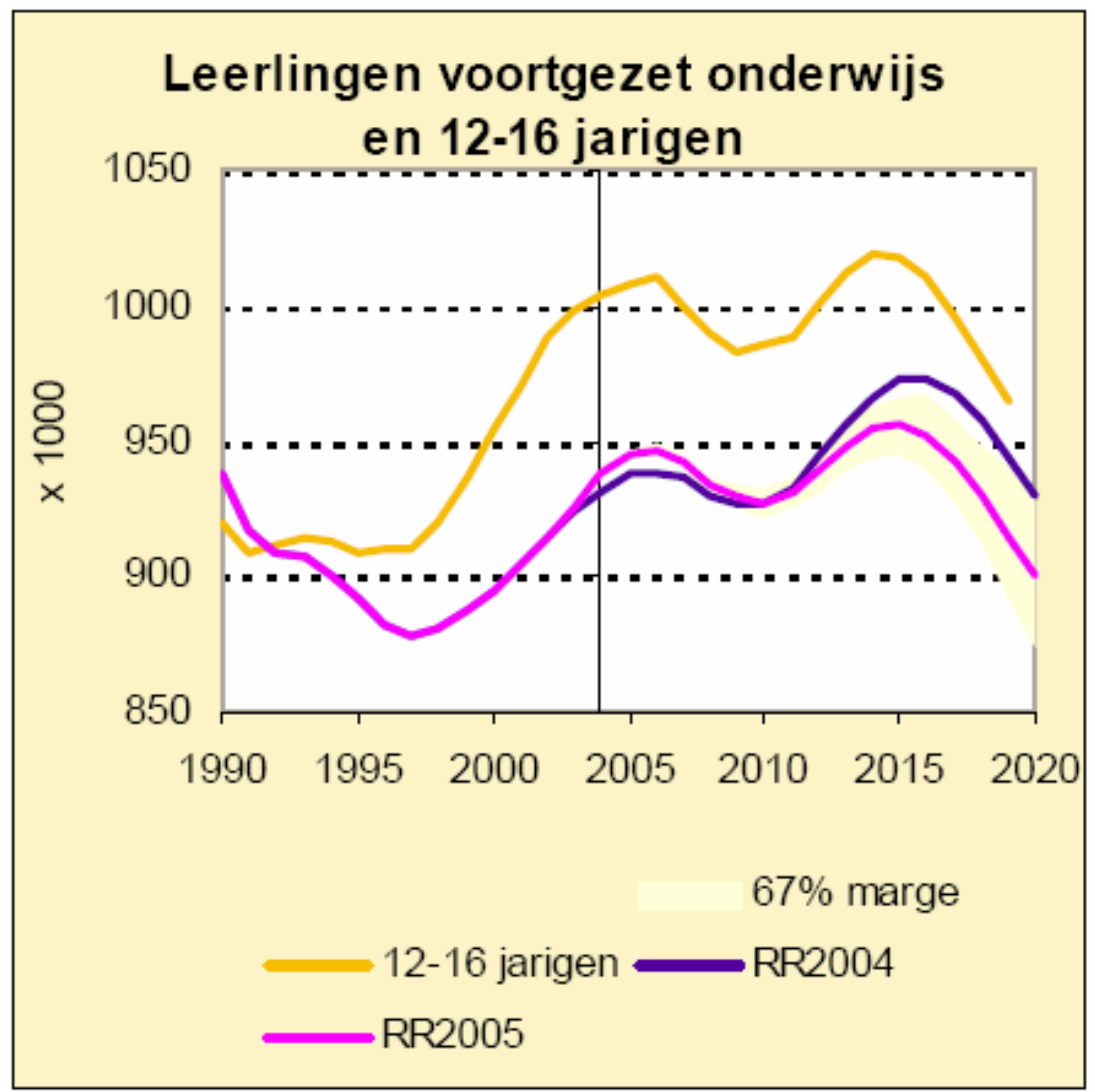

Bron: OCW (2006)

Wat betreft de onderwijssector is het in beginsel mogelijk om de OCW-Referentieraming te gebruiken in plaats van de CBS-bevolkingsprognoses. Mede om de twee bovenstaande redenen kiezen we voor de CBS-bevolkingsprognoses in plaats van de OCW-Referentieraming voor de onderwijssoorten. De leerlingenen studentenramingen van OCW zijn pas optimaal te gebruiken als duidelijk is hoe de relatie is tussen aantallen werkzame docenten en aantallen leerlingen in de verschillende onderwijssoorten, in het bijzonder binnen het voortgezet, middelbaar en hoger onderwijs. De noodzaak voor het gebruik van OCWgegevens is minder groot voor het basisonderwijs en voortgezet ondewijs, omdat zoals in de figuren 3.1 en 3.2 duidelijk werd, het aantal leerlingen voor deze onderwijssoorten sterk gerelateerd is aan het aantal 4-11 jarigen respectievelijk 12-16 jarigen. Voor het middelbaar en hoger onderwijs is een dergelijk relatie overigens niet eenvoudig te leggen. Een ander nadeel van de OCW-Referentieraming is dat deze is gebaseerd op tijdreeksen die pas beginnen 
in het jaar 1990 (zie ook de figuren 3.1 en 3.2). Omdat we ook deze historische reeksen nodig hebben voor ons schattingsmodel, verliezen we bij het gebruik van de OCW-Referentieraming twee waarnemingen in de dataset van onze huidige tijdreeksen voor de werkgelegenheid van sector x beroep (1988-2003).

\section{Figuur 3.3}

Ontwikkeling van het aantal 65-79 jarigen en 80+'ers op peildatum 1 januari, tellingen t/m 2006, prognose vanaf 2007

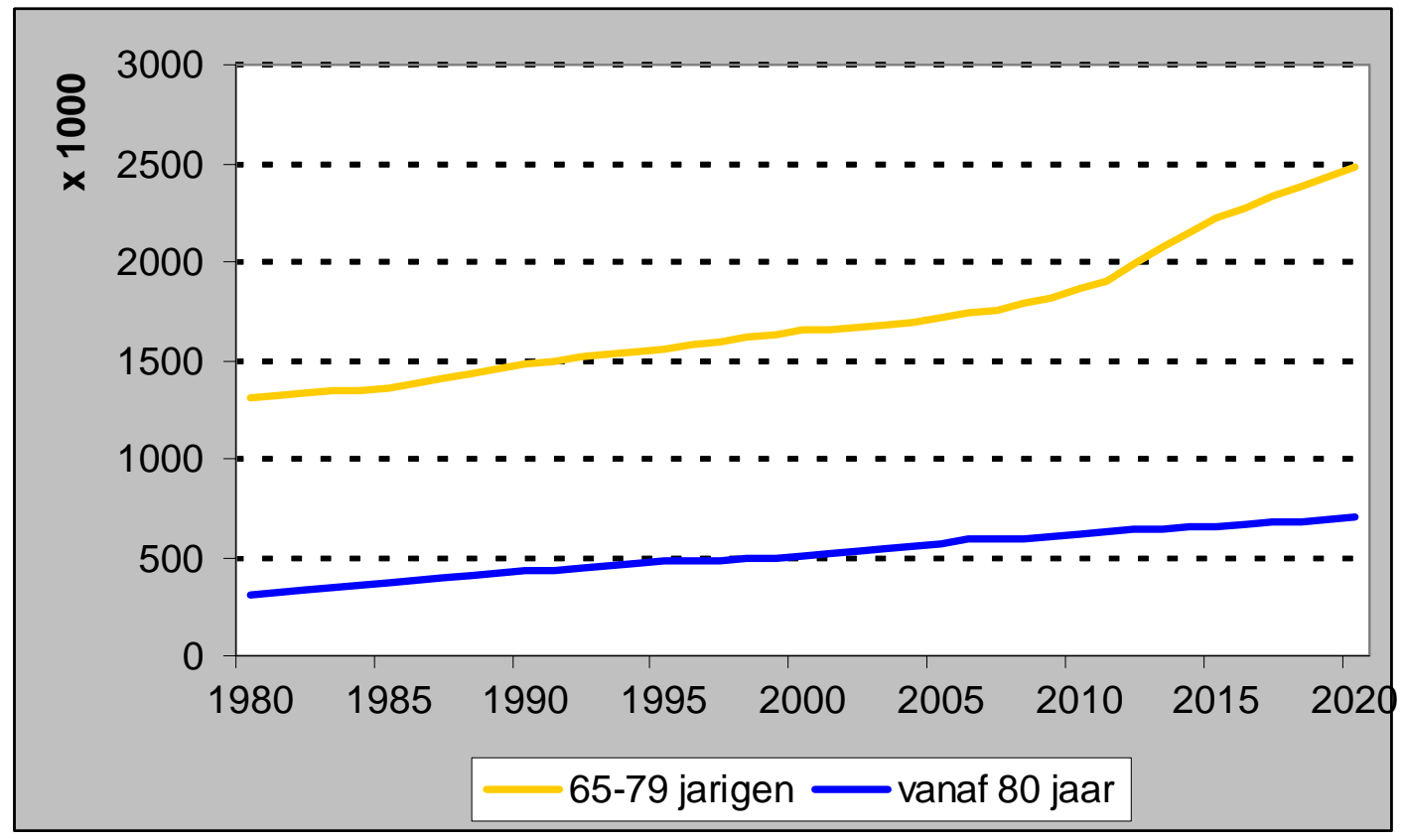

Bron: CBS

Voor de werkgelegenheidsontwikkeling van de beroepen in de zorgsector is de bevolkingsgroei van het aantal ouderen van belang. In figuur 3.3 is het aantal ouderen van 65 tot 80 jaar en vanaf 80 jaar oud (dubbele vergrijzing) weergegeven. Voor beide leeftijdsklassen van ouderen is er sprake van een duidelijke stijging over de tijd. Vanaf 2011 treedt er een versnelling op van het aantal 65-79 jarigen. Deze versnelling houdt verband met de zogenaamde 'baby boom' generatie die 65 jaar wordt.

\section{Verband tussen demografische variabelen en werkgelegenheidsgroei}

Om gebruik te kunnen maken van de CBS-bevolkingsprognoses worden in tabel 3.3 de leeftijdsklassen gekoppeld aan de beroepssegmenten die verband houden met onderwijs en zorg. De bevolkingsgroei in deze leeftijdsklassen wordt 
verderop in deze paragraaf gecorreleerd aan de werkgelegenheidsontwikkeling van de genoemde beroepssegmenten in de sectoren 'kwartaire diensten' (waaronder de sector gezondheidszorg) en 'overheid en onderwijs' (waaronder de sector onderwijs) te verklaren.

Tabel 3.3

Onderwijs- en Zorgberoepen en de leeftijdsklassen waarvan de bevolkingsomvang relevant wordt verondersteld voor de werkgelegenheid in deze beroepen

ROA Naam beroepssegment (CBS) Leeftijdsklassen

$\mathrm{nr}$.

Onderwijs

3 Lagere docenten sportvakken Niet van toepassing (te klein

12 Middelbare docenten transport-, sportvakken

beroepssegment)

23 Hogere pedagogische beroepen

18-24 jarigen (jong volwassenen)

4-19 jarigen (basisonderwijs, VMBO, voortgezet onderwijs onderbouw, praktijklessen beroepsonderwijs)

35 Wetenschappelijke pedagogische beroepen

16-24 jarigen (bovenbouw voortgezet

onderwijs, hoger onderwijs)

Zorg

8 Lagere (para)medische beroepen

Voor alle zorgberoepen:

Lagere verzorgende beroepen

Middelbare (para)medische beroepen

Middelbare verzorgende beroepen ed.

Leeftijdsklassen

Hogere (para)medische beroepen

vanaf 65+, 65-79 jaar (vergrijzing) en 80+

33 Hogere verzorgende beroepen

(dubbele vergrijzing)

39 Wetenschappelijke (para)medische beroepen ed.

Opmerking: Zie voor verdere toelichtingen op de indelingen Bijlagen B, C, D.

Hoewel er een min of meer arbitraire keuze is gemaakt voor de leeftijdsgrenzen per beroepssegment in het onderwijs, zijn in het beroepenmodel veel verschillende leeftijdscategorieën op hun verklaringskracht getoetst (zie volgende paragraaf).

In tabel 3.4 is het verband tussen bevolkingsomvang en werkgelegenheid voor verschillende beroepssegmenten en leeftijdsklassen weergegeven aan de hand van correlatiecoëfficiënten. Het gaat hierbij om de werkgelegenheid van het gehele betreffende beroepssegment, dat wil zeggen geaggregeerd over alle sectoren. In het beroepenmodel wordt de (relatieve) werkgelegenheidsontwikkeling voor elke relevante combinatie van sector en beroepssegment 
verklaard aan de hand van de bevolkingsgroei in de betreffende leeftijdsklassen. De correlaties die in tabel 3.4 gepresenteerd worden geven slechts een zeer voorlopige indicatie voor een mogelijke relatie tussen de werkgelegenheidsgroei per beroepssegment en de demografische ontwikkeling naar leeftijdsklasse, omdat er niet - zoals in het beroepenmodel - gecorrigeerd wordt voor de invloed van andere verklarende variabelen, waaronder de investeringen in kapitaal en R\&D en een exogene tijdtrend.

Tabel 3.4

Correlaties tussen de werkgelegenheidsgroei van de beroepssegmenten in het onderwijs en de zorg en de bevolkingsgroei van de leeftijdsklassen, 1988-2003

Naam beroepssegment (CBS)

Leeftijdsklassen

Onderwijs

Middelbare docenten transport-, sportvakken

Hogere pedagogische beroepen

Wetenschappelijke pedagogische beroepen

Zorg

Lagere (para)medische beroepen

Lagere verzorgende beroepen

Middelbare (para)medische beroepen

Middelbare verzorgende beroepen ed.

Hogere (para)medische beroepen

Hogere verzorgende beroepen

Wetenschappelijke (para)medische beroepen ed.

\begin{tabular}{rrr} 
4-19 jaar & 16-24 jaar & $18-24$ jaar \\
0,02 & 0,21 & 0,20 \\
0,47 & $-0,72$ & $-0,78$ \\
$-0,40$ & $-0,80$ & $-0,77$ \\
& & \\
$65-80$ jaar & $\geq 65$ jaar & $\geq 80$ jaar \\
$-0,02$ & 0,01 & $-0,01$ \\
0,66 & 0,62 & 0,65 \\
0,97 & 0,97 & 0,97 \\
0,91 & 0,93 & 0,92 \\
0,87 & 0,86 & 0,87 \\
$-0,23$ & $-0,11$ & $-0,19$ \\
0,96 & 0,93 & 0,95 \\
\hline
\end{tabular}

Uit tabel 3.4 blijkt dat de correlatie tussen de werkgelegenheid van de middelbare docenten transport-, sportvakken het sterkst is voor de jong volwassenen, en dat er zoals verwacht geen verband is met de jongste leeftijdsklassen. Voor de hogere pedagogische beroepen zijn de correlaties sterker en conform de verwachting positief voor de jongste leeftijdsklassen. Voor de wetenschappelijke pedagogische beroepen worden er uitsluitend sterke negatieve correlaties gevonden. Voor de zorgberoepen zijn de correlaties tussen werkgelegenheid en het aantal ouderen over het algemeen sterk positief, en conform de verwachting. Alleen voor de lagere (para)medische beroepen is er geen verband, terwijl er voor de hogere verzorgende beroepen een negatief verband wordt gevonden. 
Naast de ontwikkeling van het aantal jongeren en ouderen, zijn ook de productiviteit en de kwaliteit van het onderwijs en de zorg van invloed op de vraag naar personeel in het onderwijs en de zorg. Zo kan bijvoorbeeld de leerling/leraar ratio worden opgevat als een productiviteits- of kwaliteitsindicator van het onderwijs. Voor de zorg zouden soortgelijke indicatoren kunnen gelden, bijvoorbeeld met betrekking tot het aantal 'handen aan een bed'

De verkleining van de klassen vanaf de tweede helft van de jaren negentig zou een verstorende invloed kunnen uitoefenen op de correlaties tussen de werkgelegenheidsontwikkeling van beroepen in het onderwijs en het aantal jongeren. In tabel 3.5 wordt de ontwikkeling van de leerling/leraar ratio's weergegeven voor het basisonderwijs, het voortgezet onderwijs en het middelbaar beroepsonderwijs. Langere tijdreeksen zijn niet beschikbaar, en bovendien zijn er geen prognoses beschikbaar van deze ratio's. Voor het primair onderwijs (basisonderwijs, speciaal basisonderwijs en voortgezet speciaal onderwijs) en het middelbaar beroepsonderwijs zijn de ratio's vanaf 1994 berekend, voor het voortgezet onderwijs vanaf $1992 .^{7}$

Uit de tabel blijkt dat de leerling/leraar ratio in het primair onderwijs sinds 1993/94 vrijwel continue is gedaald. Dit geldt ook voor het voortgezet onderwijs vanaf 1994/95 tot en met 2002/03. Daarna lijkt de klassenverkleining tot stilstand gekomen, en lijken de klassen zelfs weer groter te worden. In het mbo lijkt de klassenverkleining al eerder tot stilstand te zijn gekomen, en is er in het schooljaar 2005/06 sprake van de grootste klassen sinds het begin van de tijdreeks in 1994/1995. Overigens kan de klassengrootte een gevolg zijn van zowel doelstellingen in het beleid als van de arbeidsmarktsituatie voor leerkrachten en docenten. Zo zal bijvoorbeeld een krappe arbeidsmarktsituatie voor leerkrachten een door het beleid gewenste klassenverkleining kunnen vertragen.

De klassenverkleining in het po en het vo kan een grote invloed hebben gehad op de vraag naar leerkrachten en docenten. Zo zijn de klassen in het po $20 \%$ kleiner geworden tussen 1994/95 en 2005/06, hetgeen tot een $20 \%$ grotere vraag

7. Met dank aan Gert Korteweg van het Ministerie van OCW voor het berekenen en aanleveren van deze gegevens. 
naar leerkrachten zou kunnen hebben geleid. Dat betekent dat uitsluitend door de klassenverkleining de werkgelegenheid in het primair onderwijs met gemiddeld jaarlijks ruim anderhalf procent zou zijn gestegen.

Tabel 3.5

Ontwikkeling van de leerling/leraar ratio in het primair onderwijs (po), het voortgezet onderwijs (vo) en het middelbaar beroepsonderwijs (mbo), 1992/93-2005/2006

\begin{tabular}{lccc}
\hline Schooljaar & po & vo & mbo \\
\hline $1993 / 94$ & & 18,2 & \\
$1994 / 95$ & 19,8 & 18,7 & 19,2 \\
$1995 / 96$ & 19,5 & 18,3 & 18,4 \\
$1996 / 97$ & 19,3 & 18,0 & 18,4 \\
$1997 / 98$ & 19,2 & 17,9 & 19,0 \\
$1998 / 99$ & 18,7 & 16,7 & 18,5 \\
$1999 / 00$ & 18,4 & 16,5 & 18,4 \\
$2000 / 01$ & 17,7 & 15,5 & 19,0 \\
$2001 / 02$ & 17,1 & 15,0 & 18,9 \\
$2002 / 03$ & 16,4 & 14,5 & 18,9 \\
$2003 / 04$ & 16,1 & 14,5 & 19,2 \\
$2004 / 05$ & 16,2 & 14,6 & 19,9 \\
$2005 / 06$ & 15,9 & 14,7 & 20,5 \\
& & & \\
\hline
\end{tabular}

Opmerkingen:

Het aantal leraren in de ratio heeft betrekking op fte's. Bij de bepaling van de aantallen leerkrachten is het overige personeel (directeuren, conciërges, etc.) niet meegerekend. Alleen bij het primair onderwijs zijn de adjunct-directeuren meegerekend, omdat deze bijna altijd tevens leerkracht zijn.

Bron: OCW.

\section{De uitbreidingvraag naar beroep tot 2010}

In deze paragraaf wordt ingegaan op de verklaringskracht van het beroepenmodel van de uitbreidingsvraag zoals dat is gepresenteerd in paragraaf 2. Eerst wordt het deel van de resultaten van de schattingsvergelijking gepresenteerd dat betrekking heeft op de uitbreiding van het beroepenmodel met de demografische exogene variabelen voor de beroepen gericht op het onderwijs en de zorg. ${ }^{8}$ Vervolgens worden de resultaten gepresenteerd van de aanpassingen in de prognoses als gevolg van de opname van de demografische exogene variabelen in het schattingsmodel.

8. Zie Cörvers en Dupuy (2006) voor een uitgebreide bespreking van de resultaten met het oorspronkelijke model. 


\section{Schattingsresultaten}

Tabel 4.1 geeft de resultaten van de schattingsvergelijkingen weer voor de invloed van de bevolkingsgroei op de werkgelegenheid in de beroepssegmenten van het onderwijs en de zorg. De selectie van de leeftijdsklassen als verklarende variabelen heeft plaatsgevonden door te kijken naar het langetermijnverband tussen de bevolkingsgroei en de werkgelegenheidsontwikkeling in de verschillende beroepssegmenten. Voor het onderwijs zijn alle leeftijden (van 4 tot en met 24 jaar) apart als verklarende variabelen voor de werkgelegenheidsgroei meegenomen. Voor de werkgelegenheid in de zorggerelateerde beroepssegmenten is er gekeken naar de relatie met de bevolkingsgroei in de verschillende vijfjaarsleeftijdsklassen van 55 jaar en ouder. De leeftijden (voor het onderwijs) en leeftijdsklassen (voor de zorg) met de hoogste verklaringskracht voor de relatieve werkgelegenheidsontwikkeling van een bepaald beroepssegment zijn geselecteerd als additionele verklarende variabelen in de 'error correction' vergelijking van paragraaf 2 .

Tabel 4.1

Schattingsresultaten voor het langetermijnverband van de demografische verklarende variabelen in het beroepenmodel van de uitbreidingsvraag, 1988-2003

\begin{tabular}{lccc}
\hline Sector & leeftijd(sklasse) & $\begin{array}{c}\text { geschatte } \\
\text { coëfficiënt }\end{array}$ & p-waarde \\
ROA nr. en naam beroepssegment (CBS) & jaar & $\hat{\beta}_{k i j}$ \\
& & & \\
& & & \\
Overheid en onderwijs & niet van toepassing \\
3 Lagere docenten sportvakken & 5 & $-5,7$ & 0,10 \\
12 Middelbare docenten transport-, sportvakken & 6 & $-2,7$ & 0,18 \\
23 Hogere pedagogische beroepen & 19 & $-1,2$ & 0,09 \\
35 Wetenschappelijke pedagogische beroepen & & & \\
& & & 0,97 \\
Kwartaire diensten (incl. gezondheidszorg) & $75-79$ & $-0,05$ & 0,26 \\
8 Lagere (para)medische beroepen & $80-84$ & $-0,85$ & 0,51 \\
11 Lagere verzorgende beroepen & $80-84$ & 0,55 & 0,04 \\
17 Middelbare (para)medische beroepen & $70-74$ & $-1,18$ & 0,54 \\
22 Middelbare verzorgende beroepen ed. & $80-84$ & 0,61 & 0,62 \\
28 Hogere (para)medische beroepen & $80-84$ & 0,65 & 0,09 \\
33 Hogere verzorgende beroepen & $70-74$ & 1,71 &
\end{tabular}

Voor de middelbare docenten transport-, sportvakken blijkt de bevolkingsontwikkeling van 5 jarigen er het meest toe te doen, voor de hogere pedagogische 
en wetenschappelijke pedagogische beroepen is dat de bevolkingsontwikkeling van 6 respectievelijk 19 jarigen. Voor de verschillende zorgberoepen blijken de vijfjaarsleeftijdsklassen tussen 70 en 85 jaar oud van belang te zijn om de werkgelegenheidsontwikkeling te voorspellen.

Uit de tabel blijkt dat de grootte en het teken van de verklarende variabelen verschilt per beroepssegment. De geschatte coëfficiënt $\left(\hat{\beta}_{k i j}\right)$ duidt op de langetermijninvloed van verklarende variabele $k$ (bevolkingsgroei) op het werkgelegenheidsaandeel van beroepssegment $i$ in sector $j$ (volgens 13-indeling van Bijlage A). De beroepssegmenten komen ook in andere sectoren voor dan de sectoren Overheid en onderwijs en Kwartaire dienstverlening, waarvoor in tabel 4.1 de resultaten zijn weergegeven. Dat betekent dat ook de geschatte coëfficiënten voor de andere sectoren een rol spelen, maar beduidend minder dan die in tabel 4.1 omdat het werkgelegenheidsaandeel van de beroepssegmenten het grootst is in Overheid en onderwijs en Kwartaire dienstverlening. Uit de tabel blijkt dat de significantie van de geschatte coëfficiënten $\left(\hat{\beta}_{k i j}\right)$ over het algemeen tegenvalt. Overigens zijn de hier niet weergegeven coëfficiënten voor de kortetermijninvloed $\left(\hat{\lambda}_{k i j}\right)$ van de bevolkingsgroei op het werkgelegenheidsaandeel niet significant (met p-waardes van ongeveer 0,6 tot 0,7 ).

Voor de lagere docenten sportvakken, de wetenschappelijke pedagogische beroepen en de wetenschappelijke (para)medische beroepen is de geschatte coëfficiënt significant op 10\%-niveau, voor de middelbare verzorgende beroepen is de geschatte coëfficiënt significant op 5\%-niveau. Daarbij komt dat alleen voor de wetenschappelijke (para)medische beroepen het teken van de coëfficiënt positief is. Intuïtief zou gesteld kunnen worden dat hoe groter de bevolking van een jongere of oudere leeftijdsklasse is, hoe groter de werkgelegenheid in de beroepen is die diensten verlenen aan deze leeftijdsklassen. Voor drie van de vier significante coëfficiënten blijken de tekens echter negatief te zijn. Het negatieve teken zou verklaard kunnen worden door het zogenaamde multicollineariteitsprobleem. Door een sterke (niet-causale) correlatie tussen de tijdreeks voor kapitaal en R\&D enerzijds en de bevolkingsgroei anderzijds, is de afzonderlijke invloed van elke verklarende variabele moeilijk te onderscheiden van de invloed van de andere verklarende variabelen. Een andere verklaring 
voor het negatieve teken kan zijn dat er niet waargenomen verklarende variabelen een rol spelen. Doordat ze niet opgenomen zijn in de schattingsvergelijking kunnen ze de schattingscoëfficiënt van de bevolkingsvariabelen beïnvloeden. Dit zou bijvoorbeeld het geval kunnen zijn voor de klassenverkleining in de verschillende onderwijssoorten. De leerling/leraar ratio's die de klassengrootte aangeven zijn niet in de schattingsvergelijking, mede omdat de tijdreeksen te kort zijn en er geen prognoses beschikbaar zijn van de ratio's.

\section{Prognoses}

In tabel 4.2 is samengevat welke invloed het gebruik van de demografische variabelen in het beroepenmodel van de uitbreidingsvraag heeft op de prognoses. In de tabel zijn de prognoses weergegeven voor zowel het oorspronkelijke als het aangepaste model. Een negatieve (positieve) schattingscoëfficiënt in tabel 4.1 heeft een neerwaartse (opwaartse) bijstelling van de prognose tot gevolg. Er blijkt dat een aanpassing van het beroepenmodel door het opnemen van demografische verklarende variabelen alleen voor de middelbare, hogere en wetenschappelijke (para)medische beroepen, en de hogere verzorgende beroepen tot een hogere prognose van de uitbreidingsvraag leidt. De vraag is echter of er voor een dergelijke aanpassing voldoende gronden zijn, gegeven de vaak insignificante verklaringskracht van demografische variabelen voor de werkgelegenheidsontwikkeling van beroepssegmenten in het onderwijs en de zorg.

Tot slot is in de Bijlagen E en F de totale werkgelegenheidsontwikkeling (19882003) weergegeven voor de verschillende beroepssegmenten die zich op het onderwijs respectievelijk de zorg richten, alsmede de jaarlijkse groei van de werkgelegenheid (uitbreidingsvraag) met en zonder de demografische variabelen in het prognosemodel, en de jaarlijkse groei van de bevolking voor de relevante leeftijden. 
Tabel 4.2

Prognoses van de uitbreidingsvraag naar beroep met en zonder de opname van de demografische verklarende variabelen in het beroepenmodel van de uitbreidingsvraag, 2004-2010

\begin{tabular}{|c|c|c|c|}
\hline Sector & leeftijd(sklasse) & $\begin{array}{r}\text { gem. jaarlijkse } \\
\text { groei }\end{array}$ & $\begin{array}{r}\text { gem. jaarlijkse } \\
\text { groei met } \\
\text { modelaanpassing }\end{array}$ \\
\hline ROA nr. en naam beroepssegment (CBS) & jaar & $\%$ & $\%$ \\
\hline \multicolumn{4}{|l|}{ Overheid en onderwijs } \\
\hline 3 Lagere docenten sportvakken & \multicolumn{3}{|c|}{ niet van toepassing } \\
\hline 12 Middelbare docenten transport-, sportvakken & 5 & 0,61 & $-1,98$ \\
\hline 23 Hogere pedagogische beroepen & 6 & 2,58 & 2,09 \\
\hline 35 Wetenschappelijke pedagogische beroepen & 19 & 0,91 & $-0,31$ \\
\hline \multicolumn{4}{|l|}{ Kwartaire diensten (incl. gezondheidszorg) } \\
\hline 8 Lagere (para)medische beroepen & $75-79$ & 1,67 & 1,47 \\
\hline 11 Lagere verzorgende beroepen & $80-84$ & 2,28 & 1,10 \\
\hline 17 Middelbare (para)medische beroepen & $80-84$ & 2,20 & 2,64 \\
\hline 22 Middelbare verzorgende beroepen ed. & $70-74$ & 1,63 & 0,37 \\
\hline 28 Hogere (para)medische beroepen & $80-84$ & 2,20 & 2,81 \\
\hline 33 Hogere verzorgende beroepen & $80-84$ & 2,01 & 2,64 \\
\hline 39 Wetenschappelijke (para)medische beroepen ed. & $70-74$ & 1,67 & 3,30 \\
\hline
\end{tabular}

\section{Conclusies}

In dit werkdocument staan de achtergronden en de modelspecificatie van het beroepenmodel van de uitbreidingsvraag centraal. Het gaat hierbij vooral om een analyse van de relevantie van exogene variabelen die de werkgelegenheidsontwikkeling van beroepen in de gezondheidszorg en het onderwijs kunnen verklaren. Daarbij wordt niet zo zeer ingegaan op de technische aspecten van het model (zie daarvoor Cörvers en Dupuy, 2006), als wel op de werking van het model in algemene termen en de prognoseresultaten.

Bij de keuze van verklarende variabelen in het beroepenmodel wordt gelet op de theoretische onderbouwing, de beschikbaarheid van tijdreeksen, de beschikbaarheid van prognoses, en de voorspelkracht van het model en de plausibiliteit van de uitkomsten. De correlatiecoëfficiënten tussen de bevolkingsgroei van jongere en oudere leeftijdsklassen enerzijds, en de werkgelegenheidsgroei van beroepen gericht op het onderwijs en de zorg anderzijds, wijzen op een verband tussen beide variabelen. Dit betekent dat er inderdaad aanwijzingen zijn dat we zouden kunnen spreken van een groengeleide werkgelegenheidsgroei in het onderwijs en een grijsgedreven werkgelegenheidsgroei in de zorg. 
Er is een analyse gemaakt van de betekenis van het toevoegen van verklarende variabelen over de demografie voor de voorspelkracht van het beroepenmodel van de uitbreidingsvraag. Het gaat daarbij om het effect van het aantal jongeren en ouderen op de vraag naar arbeidskrachten in het onderwijs en de zorg. Aangezien het Centraal Bureau voor de Statistiek (CBS) bevolkingsprognoses voor alle leeftijdsklassen maakt, kunnen deze prognoses als exogene variabelen in het beroepenmodel van de uitbreidingsvraag worden toegevoegd.

Gebleken is dat er positieve correlaties zijn tussen de werkgelegenheid van de middelbare docenten transport-, sportvakken en de hogere pedagogische beroepen enerzijds en de bevolkingsgroei van jongeren anderzijds. Voor de wetenschappelijke pedagogische beroepen worden er echter uitsluitend sterke negatieve correlaties gevonden. Voor de zorgberoepen zijn de correlaties tussen werkgelegenheid en het aantal ouderen over het algemeen sterk positief, en conform de verwachting. De vraag is echter of er voor een aanpassing van beroepenmodel voldoende gronden zijn, gegeven de vaak insignificante verklaringskracht van demografische variabelen voor de werkgelegenheidsontwikkeling van beroepssegmenten in het onderwijs en de zorg.

Verklaringen voor de geringe verklaringskracht van de geschatte coëfficiënten, met vaak 'verkeerde' tekens, kunnen gelegen zijn in de multicollineariteit met andere verklarende variabelen in het model, en in 'misspecificatie' doordat er niet-geobserveerde verklarende variabelen (bijv. de klassengrootte) van invloed zijn op de schattingscoëfficiënten. Daarnaast houden de sectorprognoses van het Centraal Planbureau (CPB) al deels rekening met de invloed van demografische ontwikkelingen op de werkgelegenheid. Dit geldt in het bijzonder voor de zorgsector. De sector onderwijs maakt echter deel uit van de grote sector 'overheid en onderwijs', waardoor er voor deze sector eerder een toename van de verklaringskracht verwacht zou kunnen worden door het toevoegen van additionele verklarende variabelen in het beroepenmodel dan voor de zorgsector. De analyses bevestigen wijzen echter eerder op het omgekeerde.

Van belang voor een betere schatting van de uitbreidingsvraag zou kunnen zijn dat er, indien mogelijk, nieuwe datareeksen worden samengesteld die beter aansluiten bij de indeling van de verschillende (sub)sectoren in het onderwijs en 
de gezondheidszorg, en ook bij de aanpassingen in de nieuwere versies van de Athena-indeling. Zo zou er, mede door de omvang van de beroepsgroep leerkrachten basisonderwijs, een aparte tijdreeks voor deze beroepsgroep kunnen worden samengesteld in plaats van de huidige samenvoeging met andere beroepsgroepen van het voortgezet onderwijs. Voor de docentenberoepen dient nagegaan te worden wat de relevantie van de bevoegdheden is voor het werken binnen subsectoren van het onderwijs. Eventueel kunnen docentenberoepen van dezelfde richting maar van verschillende bevoegdheden (1e graads en WO versus $2 \mathrm{e}$ en $3 \mathrm{e}$ graads) worden samengevoegd in het beroepenmodel van de uitbreidingsvraag. Alle genoemde aanpassingen komen feitelijk neer op het hanteren van een andere dan de huidige 2-digit-beroepenindeling van het CBS. Deze nieuwe indeling zou dan gebaseerd worden op een iets andere clustering van 3-digit beroepen die zich richten op het onderwijs en de zorg. De 3-digitindeling die door het ROA gebruikt wordt bij de presentatie van de resultaten hoeft dan dus niet aangepast te worden.

In het hier geschatte model met de huidige classificaties en tijdreeksen, zou er voor enkele beroepssegmenten met significante schattingscoëfficiënten van de demografische variabelen op 5\%- of $10 \%$-niveau overwogen kunnen worden om het beroepenmodel met deze exogene variabelen uit te breiden. Het betreft hier de beroepssegmenten van de lagere docenten sportvakken, de middelbare verzorgende beroepen, de wetenschappelijke pedagogische beroepen en de wetenschappelijke (para)medische beroepen. Toch dient er hierbij gewaakt te worden voor ad hoc aanpassingen van het model, en dienen de aanpassingen van het beroepenmodel voor de zorg en het onderwijs betere resultaten op te leveren dan nu het geval is. De analyses in dit werkdocument laten zien dat er op dit moment onvoldoende redenen zijn om het beroepenmodel voor de zorg en het onderwijs anders te specificeren.

\section{Referenties}

Borghans, L., H. Heijke (1994), Een random-coëfficiënten-model voor het voorspellen van de beroepenstructuur van bedrijfstakken, ROA-W-1994/1, Universiteit Maastricht.

Bos, F., R. Douven, E. Mot (2004), Vier toekomstscenario's voor overheid en zorg, CPB Document, No. 72, Den Haag. 
Centraal Planbureau (1990), ATHENA Een bedrijfstakkenmodel voor de Nederlandse economie, Werkdocument No. 30, Den Haag.

Centraal Planbureau (2004), Vier vergezichten op Nederland: Productie, arbeid en sectorstructuur in vier scenario's tot 2040, Bijzondere CPB-publicatie, Den Haag.

Centraal Planbureau (2005), Werkgelegenheid en toegevoegde waarde per bedrijfstak, 20012020 en 2021-2040, CPB Memorandum, 14 januari, Den Haag.

Centraal Planbureau (2005a), Centraal Economisch Plan 2005, Den Haag.

Centraal Planbureau (2006), Athena A Multi-sector model of the Dutch Economy, CPB Document No. 105, Den Haag.

Cörvers, F., A. de Grip, H. Heijke (2002), Beyond manpower planning: a labour market model for the Netherlands and its forecasts to 2006, in: M. Neugart and K. Schömann (eds), Forecasting Labour Markets in OECD countries, Edward Elgar, pp. 185-223.

Cörvers, F., A. Dupuy, S. Dijksman, B. Golsteyn, M. Hensen (2004), Methodiek arbeidsmarktprognoses en -indicatoren 2003-2008, ROA-W-2004/2, Universiteit Maastricht.

Cörvers, F., A. Dupuy, S. Dijksman, B. Golsteyn, B. Kriechel, R. Montizaan (2006), Methodiek arbeidsmarktprognoses en -indicatoren 2005-2010, ROA-W-2006/6, Universiteit Maastricht.

Cörvers, F., A. Dupuy (2006), Explaining the occupational structure of Dutch sectors of industry, 1988-2003, ROA-W-2006/7E, Universiteit Maastricht.

EIM (2005), Kleinschalig Ondernemen, editie april, Zoetermeer.

Engle, R.F., C.W.J. Granger (1987), Co-integration and error correction: Representation, estimation, and testing, Econometrica, Vol. 55, pp. 251-276.

Mark, N.C. M. Ogaki and D. Sul (2003), Dynamic Seemingly Unrelated Cointegration Regression, NBER Technical Working Paper, No. 292, Cambridge Massachusetts.

OCW (2006), Onderwijsdeelname 1990-2020, Beelden anno 2005, Interne publicatie van het Ministerie van Onderwijs, Cultuur en Wetenschap, Den Haag.

Researchcentrum voor Onderwijs en Arbeidsmarkt (2002), ROA-classificatiegids 2002, ROA-R-2002/3, Universiteit Maastricht.

Researchcentrum voor Onderwijs en Arbeidsmarkt (2003), De arbeidsmarkt naar opleiding en beroep 2008, ROA-R-2003/11, Universiteit Maastricht.

Researchcentrum voor Onderwijs en Arbeidsmarkt (2005), De arbeidsmarkt naar opleiding en beroep 2010, ROA-R-2005/9, Universiteit Maastricht. 


\section{Bijlage A Indeling naar bedrijfstakken, i.h.b. voor zorg en onderwijs}

1 Landbouw en visserij

2 Voeding

3 Chemie

4 Metaal en elektrotechniek

5 Overige industrie

6 Energie

7 Bouw en onroerend goed

8 Handel en reparatie

9 Transport en communicatie

10 Bank- en verzekeringswezen

11 Horeca en zakelijke dienstverlening

12 Kwartaire diensten (incl. gezondheidszorg)

13 Overheid en onderwijs

Differentiatie van zorg- en onderwijssectoren in ROA- en CBSclassificaties

ROA nr. en naam

SBI code en naam

\section{Kwartaire diensten}

31 Gezondheidszorg

85100 Gezondheidszorg

85200 Veterinaire diensten

85300 Welzijnszorg

32 Overige kwartaire diensten

73100 Natuurwet. speur-/ontwikkelingsw.

73200 Maatschappij-/geesteswet. speur-/ontwikkelingsw.

91100 Bedrijfs-/werkgev.-/beroepsorganisaties

91200 Werknemersorganisaties

91300 Levensbesch./politieke organ.;ov. ideele organ. ed

92100 Activ. op gebied film/video

92200 Radio/tv

92300 Overig amusement/kunst 
92500 Cult. uitl.centra/openb. arch./musea/dieren-/plantentuin ed 92600 Sport

92700 Ov. recreatie

\section{Overheid en onderwijs}

33 Onderwijs

75100 Openbaar bestuur

75200 Overheidsdienst.

75300 Verpl. soc. verzekeringen

99000 Extra-territoriale lichamen/organisaties

34 Overheid

80100 Basisonderwijs voor leerplichtingen/speciaal onderwijs

80200 Voortgezet onderwijs

80300 Hoger onderwijs

80400 Overig onderwijs 


\section{Bijlage B Indeling naar beroepssegmenten}

ROA nr.

CBS-naam

(ZORG- en ONDERWIJS-beroepen cursief)

\section{Elementaire beroepen}

1 Elementaire beroepen

\section{2-11 Lagere beroepen}

2 Lagere niet-specialistische beroepen

3 Lagere docenten sportvakken (ONDERWIJS)

4 Lagere agrarische beroepen

5 Lagere wiskundige, natuurwetenschappelijke beroepen

6 Lagere technische beroepen

7 Lagere transportberoepen

8 Lagere (para)medische beroepen (ZORG)

9 Lagere administratieve, commerciële beroepen e.d.

10 Lagere beveiligingsberoepen

11 Lagere verzorgende beroepen (ZORG)

\section{2-22 Middelbare beroepen}

12 Middelbare docenten transport-, sportvakken (ONDERWIJS)

13 Middelbare agrarische beroepen

14 Middelbare wiskundige, natuurwetenschappelijke beroepen

15 Middelbare technische beroepen

16 Middelbare transportberoepen e.d.

17 Middelbare (para)medische beroepen (ZORG)

18 Middelbare administratieve, commerciële beroepen e.d.

19 Middelbare juridische, bestuurlijke beveiligingsberoepen

20 Middelbare taalkundige, culturele beroepen

21 Middelbare beroepen mbt. gedrag en maatschappij

22 Middelbare verzorgende beroepen e.d. (ZORG)

\section{3-34 Hogere beroepen}

23 Hogere pedagogische beroepen (ONDERWIJS) 
24 Hogere landbouwkundige beroepen

25 Hogere wiskundige, natuurwetenschappelijke beroepen

26 Hogere technische beroepen

27 Hogere transportberoepen

28 Hogere (para)medische beroepen (ZORG)

29 Hogere administratieve, commerciële beroepen

30 Hogere juridische, bestuurlijke, beveiligingsberoepen

31 Hogere taalkundige, culturele beroepen

32 Hogere beroepen mbt. gedrag en maatschappij e.d.

33 Hogere verzorgende beroepen (ZORG)

34 Managers (HBO werk- en denkniveau)

\section{5-43 Wetenschappelijke beroepen}

35 Wetenschappelijke pedagogische beroepen (ONDERWIJS)

36 Wetenschappelijke landbouwkundige beroepen

37 Wetensch. wiskundige, natuurwetenschappelijke beroepen

38 Wetenschappelijke technische beroepen

39 Wetenschappelijke (para)medische beroepen (ZORG)

40 Wetenschappelijke economische, administratieve beroepen

41 Wetenschappelijke juridische,bestuurlijke beroepen

42 Wetenschappelijke beroepen mbt. gedrag en maatschappij

43 Managers (wetenschappelijk werk- en denkniveau) 


\section{Bijlage C Beroepssegmenten en -groepen in het onderwijs, volgens SBC '92}

ROA nr.

Nr. SBC Beroepssegment (CBS-naam) Beroepsgroep (ROA-naam)

3

22 LAGERE DOCENTEN SPORTVAKKEN

234 Lagere docenten sportvakken Zweminstructeurs

12

42 MIDDELBARE DOCENTEN TRANSPORT-, SPORTVAKKEN

427 Middelbare docenten transportvakken

434 Middelbare docenten sportvakken

23

62 HOGERE PEDAGOGISCHE BEROEPEN

621 Hogere pedagogische beroepen (ongeacht specialisatie)

622 Hogere onderwijskundige, pedagogische beroepen

623 Docenten basisonderwijs, algemeen vormende vakken

625 Docenten exacte, (para)medische, verzorgende vakken $\left(2^{\mathrm{e}}\right.$ en $3^{\mathrm{e}}$ gr.)

Rij-instructeurs

Sportinstructeurs

Docenten $2^{\mathrm{e}}$ en $3^{\mathrm{e}}$ graads zonder specialisatie

Onderwijskundig medewerkers

Leraar basisonderwijs

Docenten exacte, medische en verzorgende vakken $\left(1^{\mathrm{e}}\right.$ gr.)

626 Docenten agrarische, technische, transportvakken $\left(2^{\mathrm{e}}\right.$ Docenten landbouw en techniek $\left(2^{\mathrm{e}}\right.$ en $3^{\mathrm{e}}$ gr.)

631 Docenten economische, administratieve, juridische vakken $\left(2^{\mathrm{e}}\right.$ en $3^{\mathrm{e}}$ gr. $)$

633 Docenten taalkundige, culturele vakken ed.

634 Docenten sociale, psychologische vakken $\left(2^{\mathrm{e}}\right.$ en $3^{\mathrm{e}}$ gr. $)$ Docenten sociale vakken $\left(1^{\mathrm{e}} \mathrm{gr}\right.$.)

35

82 WETENSCHAPPELIJKE PEDAGOGISCHE BEROEPEN

Wetenschappelijke pedagogische beroepen (ongeacht Docent $1^{\mathrm{e}}$ graads zonder specialisatie specialisatie)

822 Wetenschappelijke onderwijskundige, pedagogische Onderwijskundigen en pedagogen beroepen

825 Docenten exacte, (para)medische, verzorgende vakken $\left(1^{\mathrm{e}}\right.$ gr. en WO)

Docenten exacte, medische en verzorgende vakken ( $1^{\mathrm{e}}$ gr.)

826 Docenten agrarische, technische, transportvakken $\left(1^{\mathrm{e}}\right.$ gr. en WO)

831 Docenten economische, administratieve, juridische vakken $\left(1^{\mathrm{e}}\right.$ gr. en WO)

gr.)

Docenten economisch-administratieve vakken $\left(1^{\mathrm{e}}\right.$ gr. $)$

Docenten talen en expressie Docenten landbouw en techniek $\left(2^{\mathrm{e}}\right.$

gr.)

Docenten economisch-administratieve vakken $\left(1^{\mathrm{e}}\right.$ gr. $)$

833 Docenten taalkundige, culturele vakken $\left(1^{\mathrm{e}}\right.$ gr. en WO) Docenten letteren ( $1^{\mathrm{e}}$ gr.)

834 Docenten sociale, psychologische vakken $\left(1^{\mathrm{e}}\right.$ gr. en Docenten sociale vakken $\left(1^{\mathrm{e}}\right.$ gr.) WO) 


\section{Bijlage D Beroepssegmenten en -groepen in de zorg, SBC '92}

ROA nr.

Nr. SBC Beroepssegment (CBS-naam)

Beroepsgroep (ROA-naam)

8

29 LAGERE (PARA)MEDISCHE BEROEPEN

292 Lagere (para)medische beroepen

11

37 LAGERE VERZORGENDE BEROEPEN

372 Lagere algemeen verzorgende beroepen ed

373 Lagere commercieel-verzorgende beroepen

17

49

492

493

494

Middelbare economisch-admini-stratieve

(para)medische beroepen

495 Middelbare verzorgend-(para)me-

dische beroepen

22

57

572

573

28

69 HOGERE (PARA)MEDISCHE BEROEPEN

692 Hogere algemene, verzorgende (para)medische beroepen

693 Hogere technisch-(para)medische beroepen

33

77 HOGERE VERZORGENDE BEROEPEN

772 Hogere verzorgende beroepen

39

89 WETENSCHAPPELIJKE (PARA)MEDISCHE BEROEPEN ED.

892 Wetenschappelijke (para)medische beroepen (excl. technisch)

893 Wetenschappelijke technisch (para)medische beroepen

Artsen

Apothekers
Verpleeghulpen en leerling-

verpleegkundigen

Hulpkrachten horeca en verzorging

Café- en snackbarhouders

Verplegenden en doktersassistenten Apothekersassistenten en medisch laboranten

Medisch secretaresses

Ziekenverzorgenden

Verzorgend personeel

Bedrijfshoofden horeca

Therapeuten en verpleegkundigen

Medisch analisten

Afdelingshoofden zorginstelling 


\section{Bijlage E Prognoseresultaten voor de beroepssegmenten van het onderwijs}
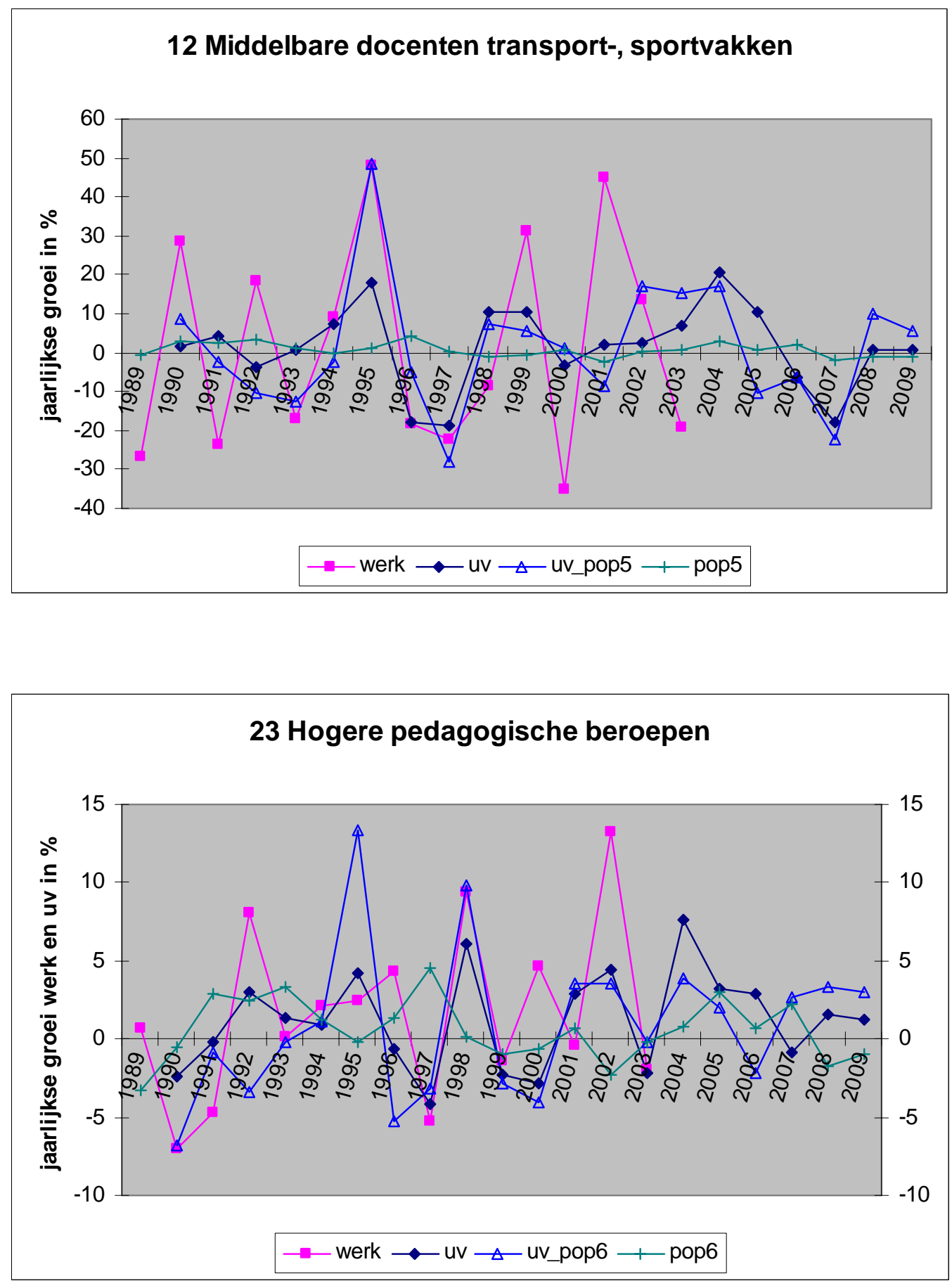


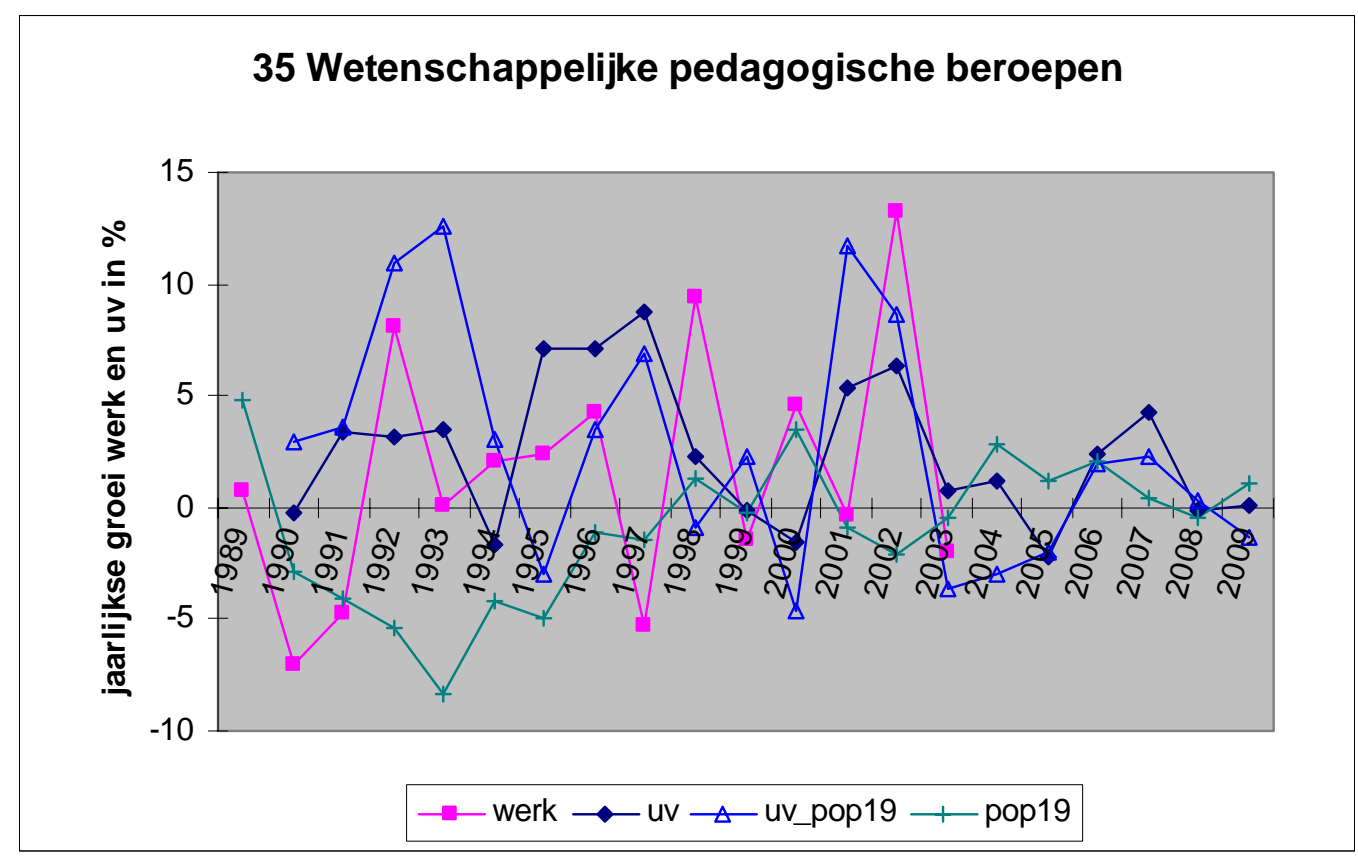




\section{Bijlage F Prognoseresultaten voor de beroepssegmenten van de zorg}
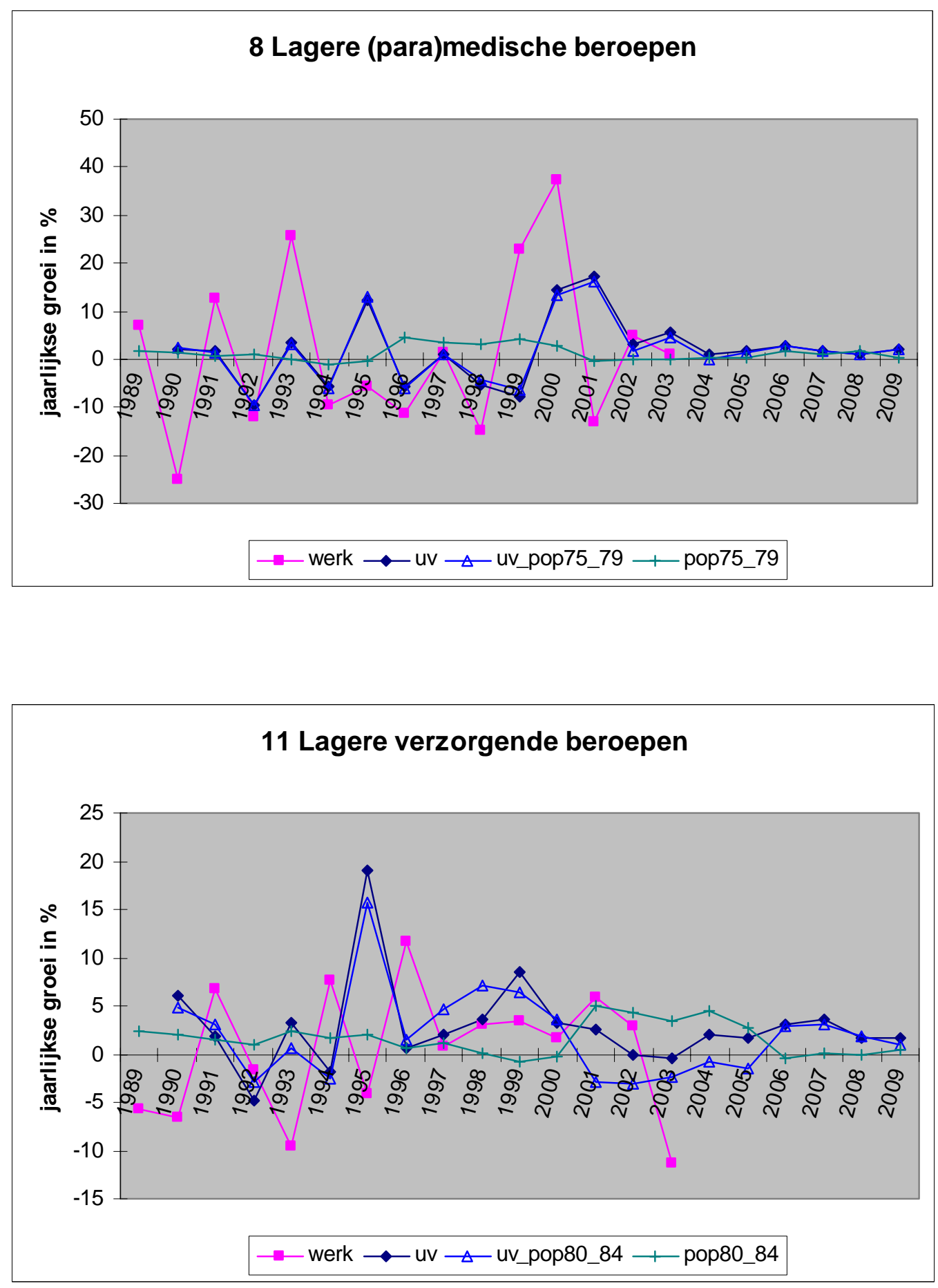

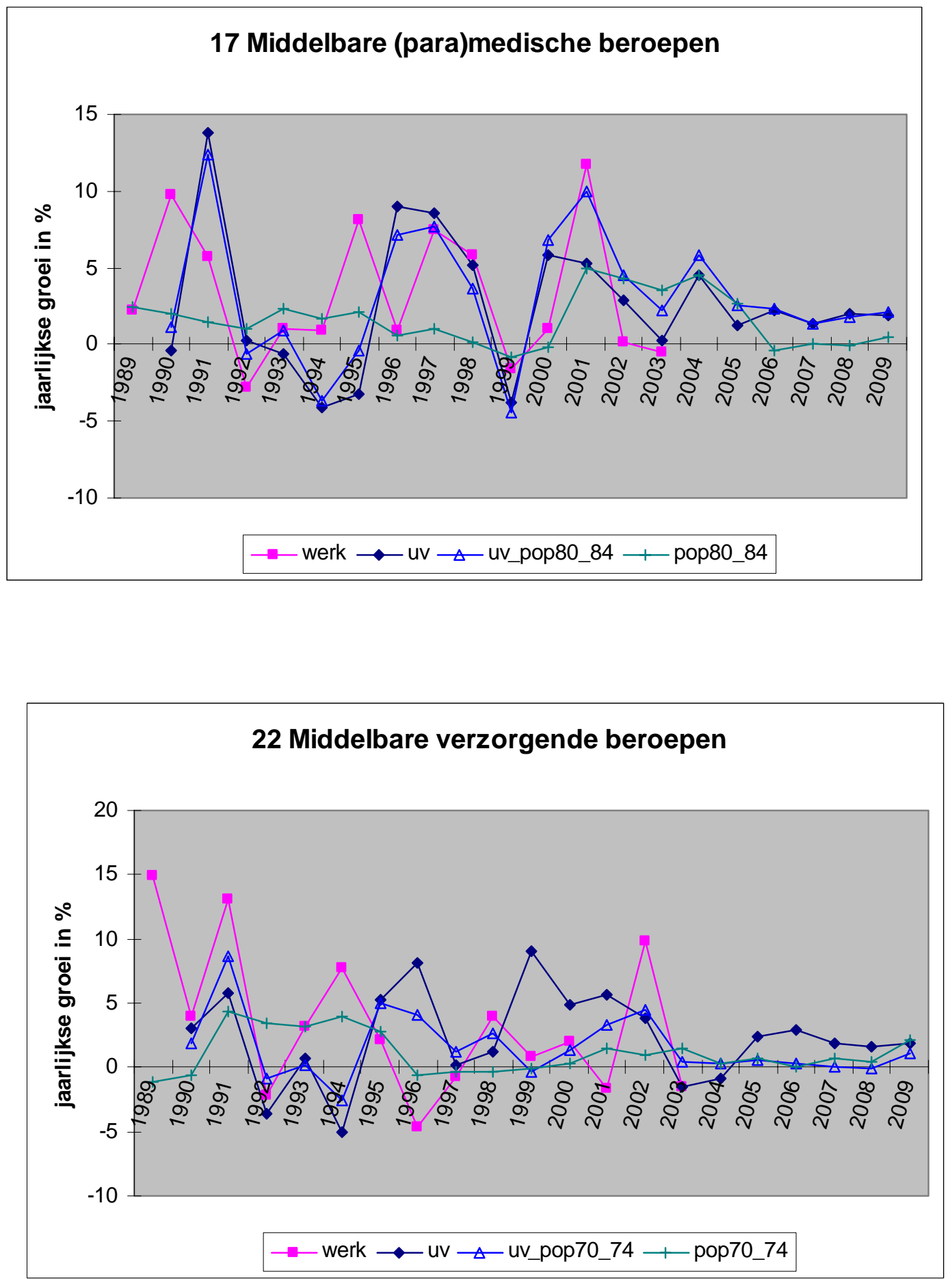

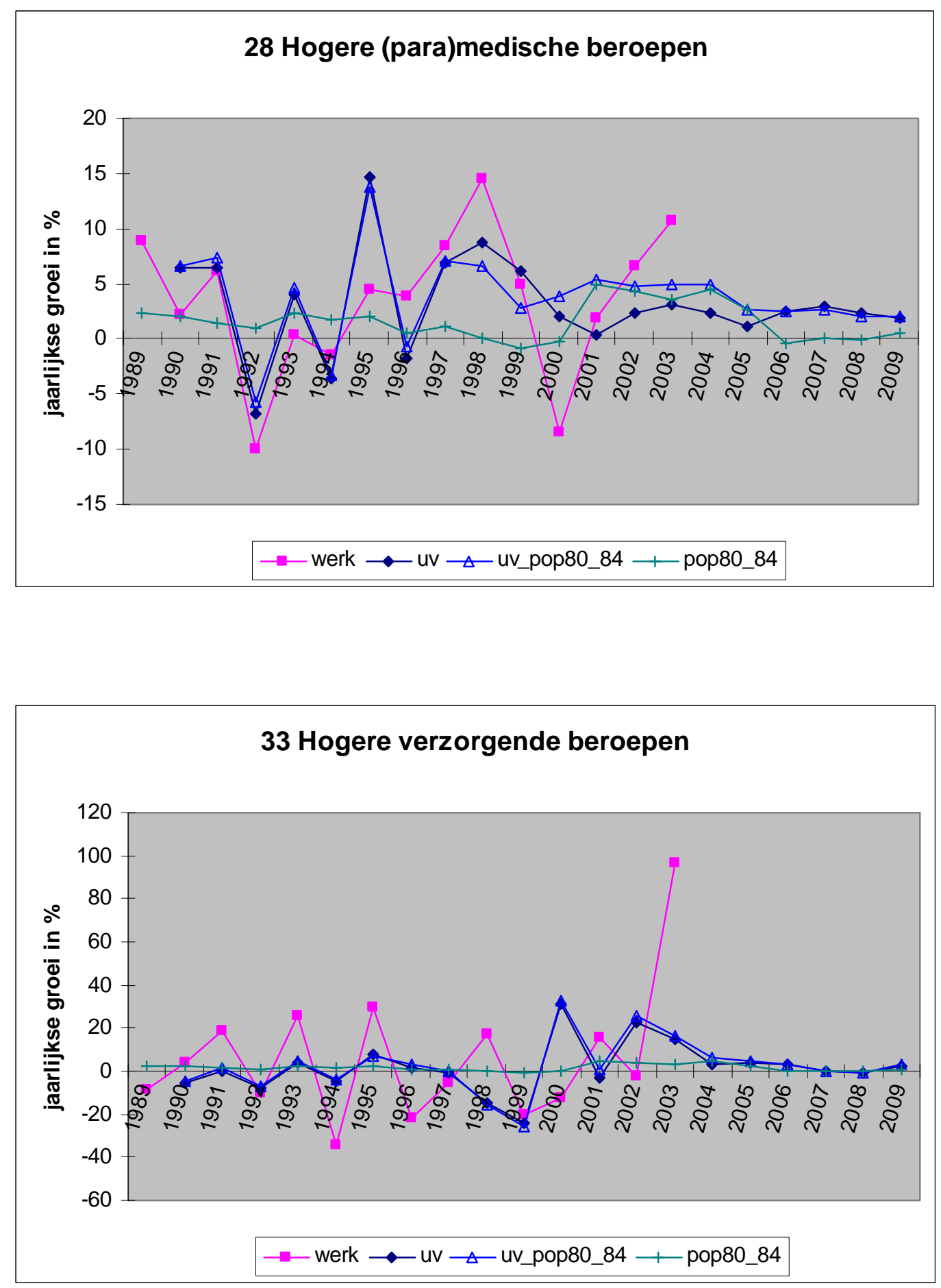


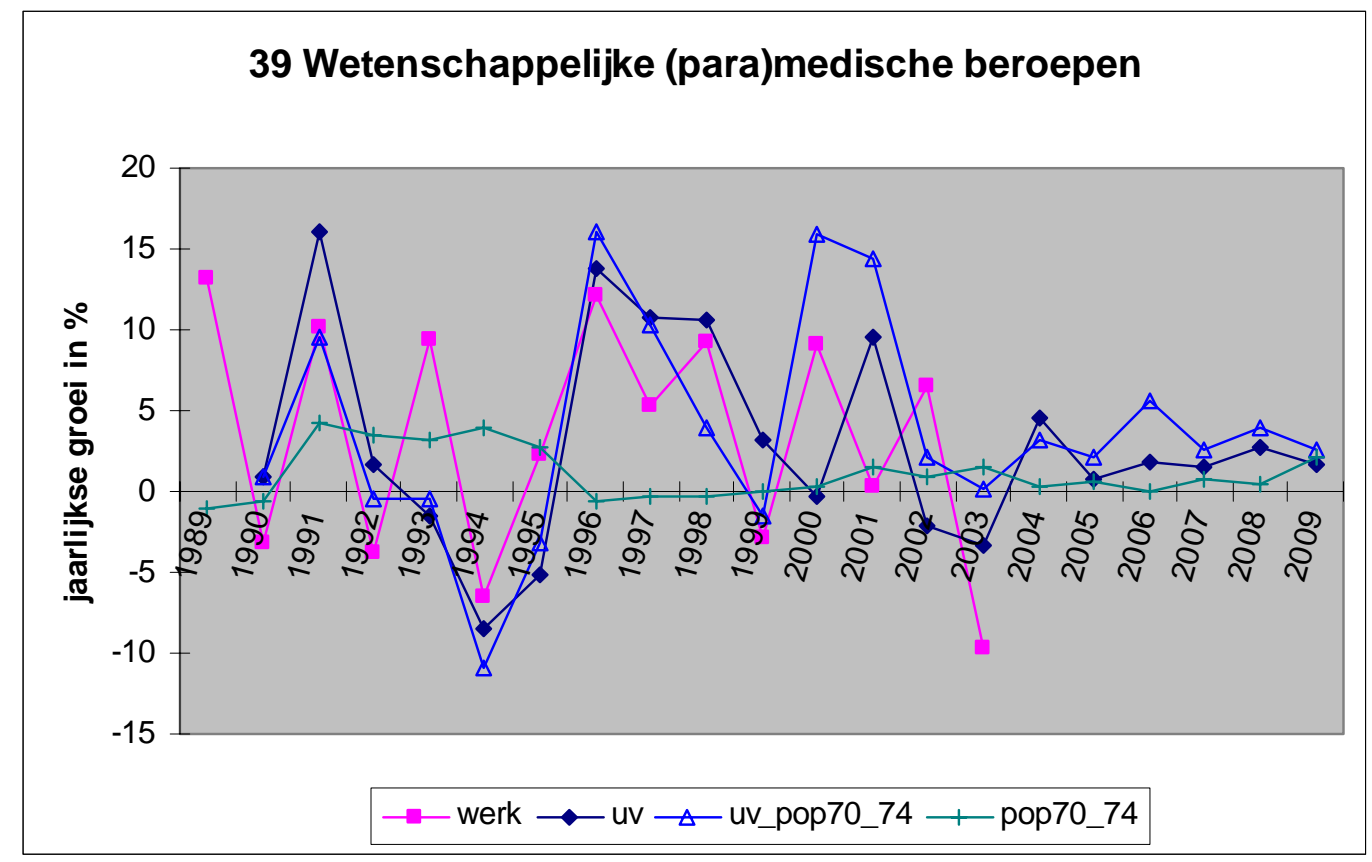

